\title{
A Review of Systems and Technologies for Smart Homes and Smart Grids
}

\author{
Gabriele Lobaccaro ${ }^{1}$, Salvatore Carlucci ${ }^{2, *}$ and Erica Löfström ${ }^{3}$ \\ 1 Department of Architectural Design, History and Technology, Norwegian University of Science and \\ Technology (NTNU), Trondheim NO-7491, Norway; gabriele.lobaccaro@ntnu.no \\ 2 Department of Civil and Transport Engineering Norwegian University of Science and Technology (NTNU), \\ Trondheim NO-7491, Norway \\ 3 Department of Computer and Information Science, Norwegian University of Science and \\ Technology (NTNU), Trondheim NO-7491, Norway; erica.lofstrom@ntnu.no \\ * Correspondence: salvatore.carlucci@ntnu.no; Tel.: +47-735-94634 \\ Academic Editor: Nyuk Hien Wong \\ Received: 8 March 2016; Accepted: 26 April 2016; Published: 7 May 2016
}

\begin{abstract}
In the actual era of smart homes and smart grids, advanced technological systems that allow the automation of domestic tasks are developing rapidly. There are numerous technologies and applications that can be installed in smart homes today. They enable communication between home appliances and users, and enhance home appliances' automation, monitoring and remote control capabilities. This review article, by introducing the concept of the smart home and the advent of the smart grid, investigates technologies for smart homes. The technical descriptions of the systems are presented and point out advantages and disadvantages of each technology and product today available on the market. Barriers, challenges, benefits and future trends regarding the technologies and the role of users have also been discussed.
\end{abstract}

Keywords: smart home; smart grid; energy management system (EMS); integrated wireless technology (IWT); smart home micro-computers (SHMC); home automation (HA)

\section{Introduction}

The European Standard EN 15232 [1] and the Energy Performance of Building Directive 2010/31/EU [2], which is in line with Directive 2009/72/EC as well as the Energy Road Map 2050 [3], promote the adoption of smart home technologies to reduce energy usage in the residential sector. In the current era of Internet of Things, their development has been recognized as having significant potential to create an interactive energy management system for homes [4]. The new information and communication technologies (ICTs) are, therefore, becoming increasingly embedded in the society by allowing faster and more efficient interaction between users and both public and private environments. They are making people's lives simpler and better especially in their home environments.

\section{State of the Art}

In the near future, all homes will have the dedicated artificial intelligence, computational power, communication skills, monitoring and controlling abilities needed to improve everyday activities. A more efficient interaction between people and home appliances will be devoted to improve comfort, healthcare, safety, security and energy savings [5,6]. Homes will hence become smart homes.

\subsection{The Advent of Smart Homes}

The interaction between humans and their surroundings can take place in different ways. People usually do everyday activities at home and numerous advantages would be gained if the environment 
could react to humans' behavior and gestures. The smart home is an intelligent space that is able to respond accordingly to the behavior of residents [7].

The concept of smart homes has been developed since the 1990s. According to one of the most recent definitions provided by Satpathy, "a home which is smart enough to assist the inhabitants to live independently and comfortably with the help of technology is termed as smart home. In a smart home, all the mechanical and digital devices are interconnected to form a network, which can communicate with each other and with the user to create an interactive space" [8]. Alam and Ali [5] define the smart home as an application that is able to automatize or assist the users through different forms such as ambient intelligence, remote home control or home automation systems. These descriptions confirm that, the primary objective of a smart home is to increase occupants' comfort and make daily life easier [9]. This goal might be achieved, in two ways: (i) by identifying the relevant human activities and increasing their automation in home environments, or (ii) by using remote home control in order to provide high comfort levels, improve security, facilitate energy management, reduce environmental emissions and save energy [10,11]. Smart homes aim to establish a better quality of living by deploying fully-automated control of appliances and providing assistive support [5]. They allow energy efficiency to be enhanced by adapting the operation of devices to occupancy. In a smart home, users and appliances are (inter)connected by an enhanced communication network comprising twisted-pair power lines or fiber optics, which transfer digital signals according to a given communication protocol. Most smart homes have a central communication device, which enables occupants to control home appliances remotely [12]. According to Le et al. [13], smart homes have the following five fundamental characteristics:

i Automation: the ability to accommodate automatic devices or perform automatic functions;

ii Multi-functionality: the ability to perform various duties or generate different outcomes;

iii Adaptability: the ability to learn, predict and meet the needs of users;

iv Interactivity: the ability to allow the interaction among users;

$\mathrm{v}$ Efficiency: the ability to perform functions in a convenient manner that saves time and costs.

However, despite their features, smart homes do not automatically become components of the smart grid [14-16].

\subsection{The Advent of the Smart Grid: A Communication Method for Smart Homes to Overcome Traditional Power Grids}

Given the rapidly rising electricity usage in private households and the increasing of environmental and regulatory restraints, the need to improve the overall efficiency of electrical grids has never been greater. Energy efficiency is hence one of the central issues that smart homes and smart grids have to face. Smart technologies monitor household energy usage, and users can control home electricity usage through a direct and bidirectional communication with home appliances. It is also expected a lower fluctuation in the load and a subsequent reduction of network dynamics, higher stability, fewer line losses, and lower operational costs in terms of matching the energy demand with the offer [17]. This is one of the strategies that appears promising to cover the performance gap created by the predicted energy performance of a building and its actual energy usage. Considering that primary energy used in buildings worldwide accounts for approximately $40 \%$ of global primary energy usage [18], the improvement of energy efficiency in buildings constitutes a critical issue concerning primary energy saving and a corresponding carbon footprint reduction [19]. This has been the motivation for the development of smart homes, in which almost all the appliances are locally manageable and controlled in real-time [17]. Several studies discuss the effect of providing feedback on energy usage to users employing different technologies [20]. It was found that, displaying real-time information on electricity usage to users, they effectively modify their behavior achieving energy saving of up to $30 \%$ [20]. In that regard, smart grids enable communication among buildings, as well as among energy generation systems. 
Although the traditional power grid has been serving humanity for about the last 100 years, it is now inadequate to face the increased demand for electricity and the deployment of sensors, active automation tools and bidirectional communication [21]. This last aspect is the most relevant feature that promotes the advent of smart grids. The traditional vision of energy production and consumption is changing because users are starting to generate and use their own energy locally, even if they are not always the only or final consumers of their generated energy. The surpluses are exported to the grid, which means that electricity transfer has to be bidirectional, i.e., energy has to flow in the two directions. In this sense, a smart grid differs from a traditional power grid through its ability to predict, monitor and manage the bidirectional energy flows. It collects information on users' behavior and actions of the various connected items in order to ensure that energy demand and supply are well balanced as well as energy is efficiently used. Smart homes hence represent the main element of the smart grid where the monitoring of real time energy and environmental data allows energy control and electricity price forecasting at transmission and distribution levels [22].

\subsection{The Role of the ICTs in Smart Homes and the Smart Grid}

As confirmed by recent studies [23,24], some of the most important advantages provided by the smart grid derive from its capability of improving performance reliability and customers' responsiveness [22]. The rapid advancements in ICT solutions and smart metering are well suited to tackling the aforementioned limitations of existing power grids. The conversion of traditional electricity grids into smart grids ensures productive interactions among energy providers, users and other stakeholders [25]. The advent of smart grids has fostered the deployment of smart meters, low-cost sensors and smart load devices, and the integration of ICTs in residential energy management programs $[19,26]$. The integration of advanced ICTs increases the efficiency of the traditional grid by providing more automation, a reliable forecast of electrical loads, and a safer operation of electrical appliances, resulting in a rise in the quality of the energy delivery service and a higher overall user satisfaction [27].

New ICT infrastructures supporting a more efficient smart grid will also include frequent price updates to follow the evolution of the balance between supply and demand in near real-time [22]. They can be set to follow load-shifting programs that offer customers a more effectively way to manage the cost of their electricity bill. They work by storing relatively inexpensive electricity during off-peak demand periods and using this stored energy during peak periods, when electricity energy prices are high. These actions allow users to reduce the cost of their electricity bill and save energy [28].

Another possibility that can consistently contribute to energy saving in buildings is to use more efficient appliances. A study conducted by Berardi's [29] estimated how much energy can be saved using highly efficient appliances in households: up to $20 \%$ in China [30], by $30 \%$ in India [31] and by $27 \%$ in Brazil [32]. The same strategy is being adopted in the US where, during the last few years, electricity consumed in buildings has slightly increased because the use of appliances, electronics, and electric lighting has risen from $24 \%$ in 1993 to more than $34 \%$ in 2009 [29].

The new method of energy distribution made possible by the advent of the smart grid has contributed to improving energy savings in the building sector. In recent years, several studies in this field supported by the European Community focused on the analysis and optimal design of modern distribution systems that aim to minimize the operational cost and maximize the profit of the users [33].

To achieve high energy efficiency in the smart grid, distributed energy resources have to be well managed and load can be reduced implementing a demand-response (DR) approach. Residential DR is strictly related to the users' behavior. It is also often linked to the price of energy during the day [34].

\subsection{The New Role of the Users}

Changes in the users' behavior are also another important factor in relation to the improvement of the energy performance of buildings. The data from Intergovernmental Panel on Climate Change (IPPC) showed that behavioral changes could affect energy savings in lighting by up to $70 \%$ [35]. 
Recently, users have become more conscious of energy usage in buildings and are increasingly interested in real-time energy monitoring and controlling devices and tools [36]. Furthermore, the market for residential energy management is poised to grow dramatically due to increased users' demands and new governmental and industry initiatives [37]. Different energy efficient routing protocols and energy management systems have been proposed [38-40] to provide information about energy usage patterns. They offer users actionable information and control features while ensuring ease of use, availability, security, and privacy [41].

\section{Aim of the Work}

This article aims to present a systematic review of existing software, hardware, and communications control systems for smart homes currently available on the market. It gives an overview of the status of smart home technologies by discussing the main relevant features and pointing out the strengths and weakness of each technology and product. It is a guide for users, who need to choose the technology that best suits their needs.

\section{Classification Criteria for the Selection of Smart Home Technologies}

The existing communication networks strive to increase the exchange of information among utilities, home appliances, and users. The diverse directionality and complexity of the existing communication devices represent a challenge. The growing trend is the development of bidirectional communication using a Home Automation Network (HAN) to monitor and control home appliances; de facto realizing a demand-response (DR) system. According to a report published by the American Council for an Energy-Efficient Economy [42], some of the systems from among the new feedback initiatives that make energy resources visible to residential users achieve the maximum feedback-related savings. If all systems are to do this, they will require a combination of useful technologies with well-designed programs that successfully inform, engage and motivate the users via the following determining factors [43]:

- Data collection: the technology allows the collection of all relevant data and provides access to them;

- Data processing: the technology allows the processing and analyzing of relevant data and can combine them;

- Data representation: the technology allows the relevant data to be made accessible to the users;

- Control and interaction capabilities: the technology enables users to access the status and monitor the functions of related technologies (bidirectional communication and interaction).

These factors need to be considered when tailoring the data that should be provided to end-users [44,45]. Collected data can be shown to users as: (i) direct feedbacks, which are the representation of the collected data typically provided in real-time; and/or (ii) indirect feedbacks, which are derived from a post-processing task and provided after the energy usage has occurred. Direct feedbacks are: real-time plus feedback (i.e., real-time information about the level of energy used by the appliance), real-time feedback (i.e., real-time premise level information), while indirect feedbacks are daily or weekly feedback, which is that are household-specific information and advice on a daily or weekly basis, estimated feedback (i.e., typically web-based energy audits with information supplied on an on-going basis), and enhanced billing (i.e., household-specific information and advice) [42]. Figure 1 shows the percentages of annual household electricity savings based on 36 studies implemented between 1995 and 2010 [42]. 


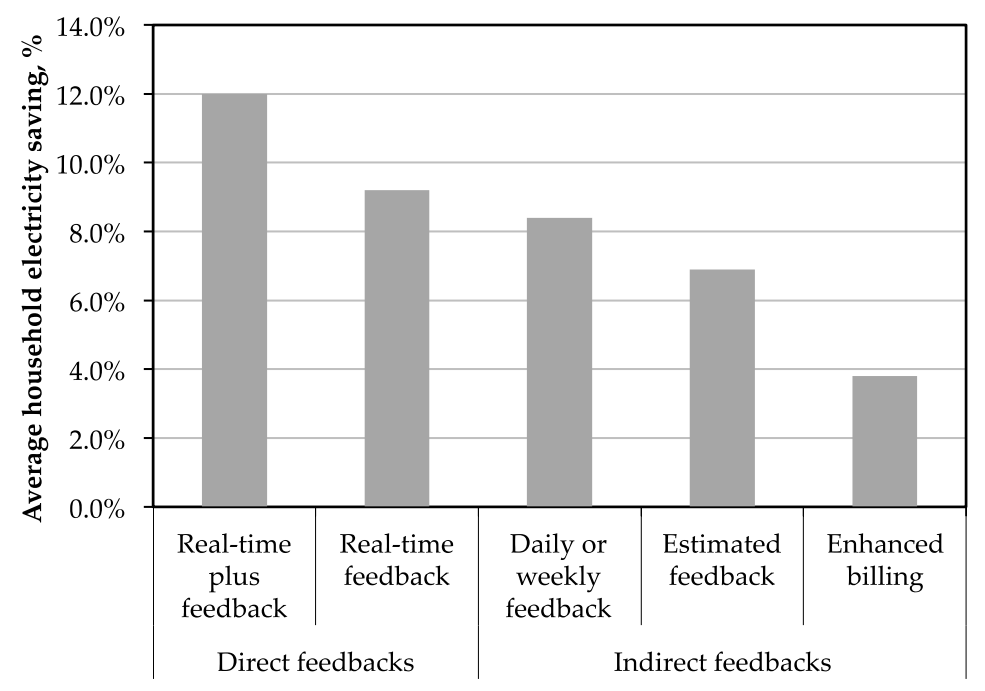

Figure 1. Average household electricity savings disaggregated by feedback type. Modified from reference [42].

Data can be presented in different ways, for example energy, peak power, cost, ecological footprint etc. and they can be compared with benchmarks and historical trends, but, to be effective, feedbacks to the end-users should be:

- Direct: the more immediate the feedback is, the more effective it is, but it requires a certain degree of knowledge and preparation from users;

- Personalized: the way of presenting data is customized to end-users' needs;

- Comparable: end-users can compare their actual electricity usage with benchmarks as well as with their historical data;

- Flexible: the feedback technology needs to be continually improved, in response to users' suggestions and requests.

It is also clear from the literature that the way to communicate the feedbacks to the end-users involves two main approaches:

- Systemic: the house exists in a systemic context, and the data, retrieved by means of a smart grid, are presented at an individual household level and compared with the average system performance [45].

- Gamification: the feedback is presented by using elements and concepts that are typical in computer games and is often integrated in a graphical user interface (GUI).

In the following sections, the most relevant technological devices and integrated software or applications today available on the market for improving the interaction between users and home appliances are presented, compared and discussed.

\section{Review of the Technologies for Smart Homes}

The most relevant technologies for smart homes discussed in this article, were grouped according to the following four categories:

1. Integrated wireless technology (IWT);

2. Home energy management system (HEMS);

3. Smart home micro-computers (SHMC);

4. Home automation (SHS/HA).

Table 1 collects and organizes all the analyzed technologies, systems and products. 
Table 1. Summary of the analyzed smart home technologies.

\begin{tabular}{|c|c|c|c|c|c|c|c|c|c|c|c|c|c|c|c|c|c|c|c|c|c|}
\hline \multirow{3}{*}{$\begin{array}{c}\text { Symstems and } \\
\text { Technologies }\end{array}$} & \multirow{3}{*}{ Company } & \multirow{3}{*}{ Country } & \multicolumn{4}{|c|}{ Automation } & \multirow{2}{*}{\multicolumn{3}{|c|}{ Visualization }} & \multirow{2}{*}{\multicolumn{8}{|c|}{ Wireless Protocol }} & \multirow{2}{*}{\multicolumn{2}{|c|}{$\begin{array}{l}\text { Commercial } \\
\text { Availability }\end{array}$}} & \multirow{2}{*}{\multicolumn{2}{|c|}{$\begin{array}{c}\text { Source } \\
\text { Availability } \\
\text { Model }\end{array}$}} \\
\hline & & & \multicolumn{3}{|c|}{ On } & \multirow[t]{2}{*}{ Off } & & & & & & & & & & & & & & & \\
\hline & & & RC & SM & $\mathrm{s}$ & & DD & PC & App & ZB & ZW & BT & RFID & GSM & IN & Wi-Fi & Other & Web & Prod & Op. & Cl. \\
\hline \multirow{12}{*}{ 桌 } & 6LoWPAN & International & - & - & - & $\sqrt{ }$ & - & - & - & - & - & - & - & - & - & - & $\sqrt{ }$ & - & $\sqrt{ }$ & & $\sqrt{ }$ \\
\hline & Bluetooth & Sweden & - & - & - & $\sqrt{ }$ & - & - & - & - & - & $\sqrt{ }$ & - & - & - & - & - & $\sqrt{ }$ & $\sqrt{ }$ & $\sqrt{ }$ & \\
\hline & DASH7 & Europe & - & - & - & $\sqrt{ }$ & - & - & - & - & - & - & - & - & - & - & $\sqrt{ }$ & - & $\sqrt{ }$ & - & $\sqrt{ }$ \\
\hline & EnOcean Technology & International & $\sqrt{ }$ & $\sqrt{ }$ & $\sqrt{ }$ & - & - & $\sqrt{ }$ & $\sqrt{ }$ & $\sqrt{ }$ & - & - & - & - & - & - & - & $\sqrt{ }$ & $\sqrt{ }$ & $\sqrt{ }$ & - \\
\hline & GSM & International & - & - & - & $\sqrt{ }$ & - & - & - & - & - & - & - & $\sqrt{ }$ & - & - & - & - & $\sqrt{ }$ & - & $\sqrt{ }$ \\
\hline & MyriaNed & $\begin{array}{l}\text { The } \\
\text { Netherlands }\end{array}$ & - & - & $\sqrt{ }$ & - & - & - & - & - & - & - & - & - & - & - & $\sqrt{ }$ & - & $\sqrt{ }$ & - & $\sqrt{ }$ \\
\hline & NeuRFon $^{\mathrm{TM}}$ Netform & International & - & - & $\sqrt{ }$ & $\sqrt{ }$ & - & - & - & - & - & - & - & - & - & - & $\sqrt{ }$ & - & $\sqrt{ }$ & - & $\sqrt{ }$ \\
\hline & RFID & International & - & - & - & $\sqrt{ }$ & - & - & - & - & - & - & $\sqrt{ }$ & - & - & - & - & - & $\sqrt{ }$ & - & $\sqrt{ }$ \\
\hline & UWB & International & - & - & - & $\sqrt{ }$ & - & - & - & - & - & - & - & - & - & - & $\sqrt{ }$ & - & $\sqrt{ }$ & & $\sqrt{ }$ \\
\hline & Wifi & USA & - & - & - & $\sqrt{ }$ & - & - & - & - & - & - & - & - & - & $\sqrt{ }$ & - & $\sqrt{ }$ & $\sqrt{ }$ & $\sqrt{ }$ & \\
\hline & Z-wave & International & - & - & - & $\sqrt{ }$ & - & - & - & - & - & - & - & - & - & - & - & $\sqrt{ }$ & $\sqrt{ }$ & & $\sqrt{ }$ \\
\hline & ZigBee & USA & - & - & - & $\sqrt{ }$ & - & - & - & $\sqrt{ }$ & - & - & - & - & - & - & - & $\sqrt{ }$ & $\sqrt{ }$ & $\sqrt{ }$ & \\
\hline \multirow{10}{*}{$\sum_{\substack{|=1\\
|}}^{\infty}$} & CISCO & USA & - & $\sqrt{ }$ & $\sqrt{ }$ & $\sqrt{ }$ & - & - & $\sqrt{ }$ & - & - & - & - & - & - & $\sqrt{ }$ & - & $\sqrt{ }$ & $\sqrt{ }$ & & $\sqrt{ }$ \\
\hline & DigitalSTROM & Germany & $\sqrt{ }$ & $\sqrt{ }$ & $\sqrt{ }$ & - & - & - & $\sqrt{ }$ & - & - & - & - & - & - & $\sqrt{ }$ & - & $\sqrt{ }$ & $\sqrt{ }$ & & $\sqrt{ }$ \\
\hline & Dreamwatts & International & - & $\sqrt{ }$ & $\sqrt{ }$ & - & $\sqrt{ }$ & - & $\sqrt{ }$ & $\sqrt{ }$ & - & - & - & - & - & $\sqrt{ }$ & - & $\sqrt{ }$ & $\sqrt{ }$ & - & $\sqrt{ }$ \\
\hline & e-GOTHAM & Europe & - & $\sqrt{ }$ & $\sqrt{ }$ & - & - & - & & $\sqrt{ }$ & - & $\sqrt{ }$ & - & - & - & $\sqrt{ }$ & - & $\sqrt{ }$ & $\sqrt{ }$ & $\sqrt{ }$ & - \\
\hline & EmonCMS & International & - & $\sqrt{ }$ & - & $\sqrt{ }$ & - & - & $\sqrt{ }$ & - & - & - & - & - & - & $\sqrt{ }$ & - & $\sqrt{ }$ & $\sqrt{ }$ & $\sqrt{ }$ & - \\
\hline & Energy Team & Italy & - & $\sqrt{ }$ & $\sqrt{ }$ & & $\sqrt{ }$ & - & $\sqrt{ }$ & - & - & - & - & $\sqrt{ }$ & - & $\sqrt{ }$ & - & - & $\sqrt{ }$ & & $\sqrt{ }$ \\
\hline & Google PowerMeter & USA & - & $\sqrt{ }$ & - & $\sqrt{ }$ & - & - & $\sqrt{ }$ & - & - & - & - & - & - & $\sqrt{ }$ & - & $\sqrt{ }$ & - & $\sqrt{ }$ & - \\
\hline & Savant & USA & $\sqrt{ }$ & $\sqrt{ }$ & $\sqrt{ }$ & $\sqrt{ }$ & $\sqrt{ }$ & $\sqrt{ }$ & $\sqrt{ }$ & - & - & - & - & - & - & & - & $\sqrt{ }$ & $\sqrt{ }$ & & $\sqrt{ }$ \\
\hline & SMARTHEMS ${ }^{\mathrm{TM}}$ & Japan & $\sqrt{ }$ & $\sqrt{ }$ & $\sqrt{ }$ & $\sqrt{ }$ & - & $\sqrt{ }$ & - & - & - & - & - & - & - & $\sqrt{ }$ & - & $\sqrt{ }$ & $\sqrt{ }$ & - & $\sqrt{ }$ \\
\hline & The Energy Navigator & Germany & $\sqrt{ }$ & $\sqrt{ }$ & $\sqrt{ }$ & - & - & $\sqrt{ }$ & - & - & - & - & - & - & - & - & $\sqrt{ }$ & - & $\sqrt{ }$ & - & $\sqrt{ }$ \\
\hline \multirow{5}{*}{ 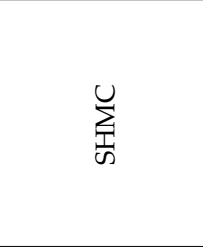 } & Arduino & Italy & - & - & - & $\sqrt{ }$ & - & $\sqrt{ }$ & - & $\sqrt{ }$ & - & - & - & - & - & $\sqrt{ }$ & - & - & $\sqrt{ }$ & $\sqrt{ }$ & - \\
\hline & Banana Pi & $\begin{array}{l}\text { United } \\
\text { Kingdom }\end{array}$ & - & - & - & $\sqrt{ }$ & - & $\sqrt{ }$ & - & $\sqrt{ }$ & - & - & - & - & - & $\sqrt{ }$ & - & - & $\sqrt{ }$ & $\sqrt{ }$ & - \\
\hline & BeagleBone & USA & - & - & - & $\sqrt{ }$ & - & $\sqrt{ }$ & - & $\sqrt{ }$ & - & - & - & - & - & $\sqrt{ }$ & - & - & $\sqrt{ }$ & $\sqrt{ }$ & - \\
\hline & Raspberry Pi & $\begin{array}{l}\text { United } \\
\text { Kingdom }\end{array}$ & - & - & - & $\sqrt{ }$ & - & $\sqrt{ }$ & - & $\sqrt{ }$ & - & - & - & - & - & $\sqrt{ }$ & - & - & $\sqrt{ }$ & $\sqrt{ }$ & - \\
\hline & Libelium Waspmote & Spain & - & - & - & $\sqrt{ }$ & - & $\sqrt{ }$ & - & $\sqrt{ }$ & - & - & - & - & - & $\sqrt{ }$ & $\sqrt{ }$ & - & $\sqrt{ }$ & $\sqrt{ }$ & - \\
\hline \multirow{5}{*}{$\frac{\mathbb{I}}{\underset{\omega}{\mathbb{S}}}$} & British Gas & $\begin{array}{l}\text { United } \\
\text { Kingdom }\end{array}$ & - & $\sqrt{ }$ & - & - & - & $\sqrt{ }$ & $\sqrt{ }$ & - & - & - & - & - & $\sqrt{ }$ & - & - & - & $\sqrt{ }$ & $\sqrt{ }$ & - \\
\hline & Control4 & USA & $\sqrt{ }$ & - & $\sqrt{ }$ & - & $\sqrt{ }$ & $\sqrt{ }$ & $\sqrt{ }$ & $\sqrt{ }$ & - & $\sqrt{ }$ & - & - & - & $\sqrt{ }$ & - & $\sqrt{ }$ & $\sqrt{ }$ & - & $\sqrt{ }$ \\
\hline & Creston & USA & $\sqrt{ }$ & $\sqrt{ }$ & $\sqrt{ }$ & - & $\sqrt{ }$ & $\sqrt{ }$ & $\sqrt{ }$ & - & - & - & - & - & - & $\sqrt{ }$ & - & $\sqrt{ }$ & $\sqrt{ }$ & - & $\sqrt{ }$ \\
\hline & GE Brillion Technology & USA & $\sqrt{ }$ & - & - & - & - & - & $\sqrt{ }$ & - & - & - & - & - & - & $\sqrt{ }$ & - & - & $\sqrt{ }$ & $\sqrt{ }$ & - \\
\hline & HomeSeer HS3 & - & - & - & - & - & $\sqrt{ }$ & $\sqrt{ }$ & $\sqrt{ }$ & - & - & - & - & - & - & - & - & $\sqrt{ }$ & - & - & $\sqrt{ }$ \\
\hline
\end{tabular}


Table 1. Cont.

\begin{tabular}{|c|c|c|c|c|c|c|c|c|c|c|c|c|c|c|c|c|c|c|c|c|c|}
\hline \multirow{3}{*}{$\begin{array}{l}\text { Symstems and } \\
\text { Technologies }\end{array}$} & \multirow{3}{*}{ Company } & \multirow{3}{*}{ Country } & \multicolumn{4}{|c|}{ Automation } & \multirow{2}{*}{\multicolumn{3}{|c|}{ Visualization }} & \multirow{2}{*}{\multicolumn{8}{|c|}{ Wireless Protocol }} & \multirow{2}{*}{\multicolumn{2}{|c|}{$\begin{array}{l}\text { Commercial } \\
\text { Availability }\end{array}$}} & \multirow{2}{*}{\multicolumn{2}{|c|}{$\begin{array}{c}\text { Source } \\
\text { Availability } \\
\text { Model }\end{array}$}} \\
\hline & & & \multicolumn{3}{|c|}{ On } & \multirow[t]{2}{*}{ Off } & & & & & & & & & & & & & & & \\
\hline & & & RC & SM & $S$ & & DD & PC & App & ZB & ZW & BT & RFID & GSM & IN & Wi-Fi & Other & Web & Prod & Op. & Cl. \\
\hline \multirow{16}{*}{ 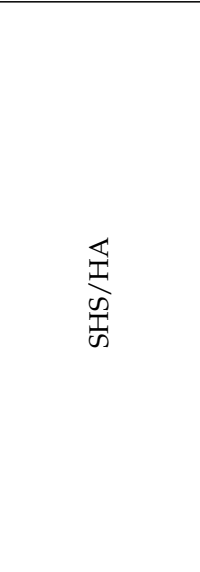 } & Honda & Japan & - & $\sqrt{ }$ & - & $\sqrt{ }$ & - & $\sqrt{ }$ & - & - & - & - & - & - & - & $\sqrt{ }$ & - & $\sqrt{ }$ & $\sqrt{ }$ & $\sqrt{ }$ & - \\
\hline & iHome & USA & & $\sqrt{ }$ & & - & - & - & $\sqrt{ }$ & - & - & - & - & - & - & $\sqrt{ }$ & - & - & $\sqrt{ }$ & & $\sqrt{ }$ \\
\hline & Iris & USA & $\sqrt{ }$ & & & - & - & - & $\sqrt{ }$ & - & $\sqrt{ }$ & $\sqrt{ }$ & - & - & - & & - & $\sqrt{ }$ & - & & $\sqrt{ }$ \\
\hline & KNX & Europe & $\sqrt{ }$ & $\sqrt{ }$ & $\sqrt{ }$ & - & $\sqrt{ }$ & $\sqrt{ }$ & $\sqrt{ }$ & $\sqrt{ }$ & - & $\sqrt{ }$ & $\sqrt{ }$ & - & - & $\sqrt{ }$ & - & $\sqrt{ }$ & $\sqrt{ }$ & $\sqrt{ }$ & - \\
\hline & LGSmart Thing & South Korea & $\sqrt{ }$ & $\sqrt{ }$ & - & - & $\sqrt{ }$ & - & $\sqrt{ }$ & - & - & & & - & _- & $\sqrt{ }$ & - & - & $\sqrt{ }$ & - & $\sqrt{ }$ \\
\hline & LonWorks & USA & $\sqrt{ }$ & & $\sqrt{ }$ & - & - & $\sqrt{ }$ & & - & - & & $\sqrt{ }$ & - & - & & $\sqrt{ }$ & - & $\sqrt{ }$ & - & $\sqrt{ }$ \\
\hline & Nexia & USA & $\sqrt{ }$ & & & - & - & - & $\sqrt{ }$ & - & $\sqrt{ }$ & & & - & - & & - & - & $\sqrt{ }$ & - & $\sqrt{ }$ \\
\hline & OpenHAB & Germany & $\sqrt{ }$ & $\sqrt{ }$ & $\sqrt{ }$ & - & - & $\sqrt{ }$ & $\sqrt{ }$ & $\sqrt{ }$ & - & $\sqrt{ }$ & & _- & - & $\sqrt{ }$ & - & $\sqrt{ }$ & $\sqrt{ }$ & $\sqrt{ }$ & \\
\hline & Panasonic & Japan & $\sqrt{ }$ & - & - & - & $\sqrt{ }$ & - & $\sqrt{ }$ & - & - & & & - & - & $\sqrt{ }$ & - & & $\sqrt{ }$ & & $\sqrt{ }$ \\
\hline & Samsung SmartThings & South Korea & $\sqrt{ }$ & - & - & - & - & - & $\sqrt{ }$ & - & - & - & - & - & - & $\sqrt{ }$ & - & $\sqrt{ }$ & - & - & $\sqrt{ }$ \\
\hline & Staples Connect & USA & $\sqrt{ }$ & - & - & - & - & - & $\sqrt{ }$ & $\sqrt{ }$ & $\sqrt{ }$ & $\sqrt{ }$ & - & - & - & $\sqrt{ }$ & - & $\sqrt{ }$ & $\sqrt{ }$ & - & $\sqrt{ }$ \\
\hline & UPnP Technology & International & - & - & - & $\sqrt{ }$ & $\sqrt{ }$ & - & - & & - & - & - & - & - & $\sqrt{ }$ & - & $\sqrt{ }$ & $\sqrt{ }$ & $\sqrt{ }$ & \\
\hline & $\begin{array}{c}\text { Vera smarter home } \\
\text { control }\end{array}$ & China & - & - & - & - & $\sqrt{ }$ & - & - & $\sqrt{ }$ & $\sqrt{ }$ & - & - & - & $\sqrt{ }$ & $\sqrt{ }$ & - & - & $\sqrt{ }$ & - & $\sqrt{ }$ \\
\hline & WeBee & USA & $\sqrt{ }$ & $\sqrt{ }$ & $\sqrt{ }$ & - & - & - & $\sqrt{ }$ & $\sqrt{ }$ & - & - & - & - & - & $\sqrt{ }$ & - & $\sqrt{ }$ & $\sqrt{ }$ & $\sqrt{ }$ & \\
\hline & Whirlpool & USA & $\sqrt{ }$ & - & - & - & $\sqrt{ }$ & - & $\sqrt{ }$ & - & - & - & - & - & - & $\sqrt{ }$ & - & - & $\sqrt{ }$ & - & $\sqrt{ }$ \\
\hline & Wink & International & $\sqrt{ }$ & - & - & - & - & - & $\sqrt{ }$ & - & $\sqrt{ }$ & $\sqrt{ }$ & - & - & - & $\sqrt{ }$ & - & - & $\sqrt{ }$ & - & $\sqrt{ }$ \\
\hline
\end{tabular}

Automation. It can be disabled (Off) or enabled (On). In the latter case, it is also reported if the automation is activated by a remote control (RC), by a smart meter (SM) or by a sensor (S); Visualization of feedbacks to users: Dashboard or display device (DD), physical component (PC), App; Adopted wireless protocol: ZigBee (ZB), Bluetooth (BT), Z-Wave (ZW), Radio Frequency Identification (RFID), Global System Mobile (GSM/GPRS), Insteon (IN), Wi-Fi and other; Commercial availability of the product: on a website (WS) or from the producer (Prod.), Source availability model: it is an open (Op.) or a close $(\mathrm{Cl}$.) source. The symbol $(\sqrt{ })$ means that is present in the system/technology, while "-" means that is not present. 


\subsection{Integrated Wireless Technology and Network}

Several studies on information and communications technologies for smart grids and smart homes can be found in literature [46]. Parikh et al. [47] presented several wireless communications options. They discuss the main challenges of each wireless technology. IWT is a communication commonly used within an office building, a private home or any other residence in order to allow internal and external short-range communication throughout smart home technology. IWTs are often preferred to wired technologies. The use of wired solutions, would be economically and/or physically prohibitive for many smart grid applications. Instead, wireless technologies give benefits such as a lower cost of equipment and installation, a quick deployment, widespread access and greater flexibility $[48,49]$.

Furthermore, IWT systems could be implemented through a GUI to monitor and control home appliances remotely. It allows integration and communication within home energy management systems, whereas IWT has some disadvantages when integrated into a smart grid. They do not currently include local renewable energy generation systems such as Photovoltaic (PV) panels.

In this section, the most used wireless communication technologies (WCTs) and network protocols suitable for home area networks are discussed and compared (Table 2).

Figure 2 shows the top-level architecture of a smart home. It includes a server/gateway/router as a connection within the house and to the smart grid. These can be installed using one or a combination of the available external networks such as phone lines, digital subscriber lines (xDSL), cable, and power line networks.

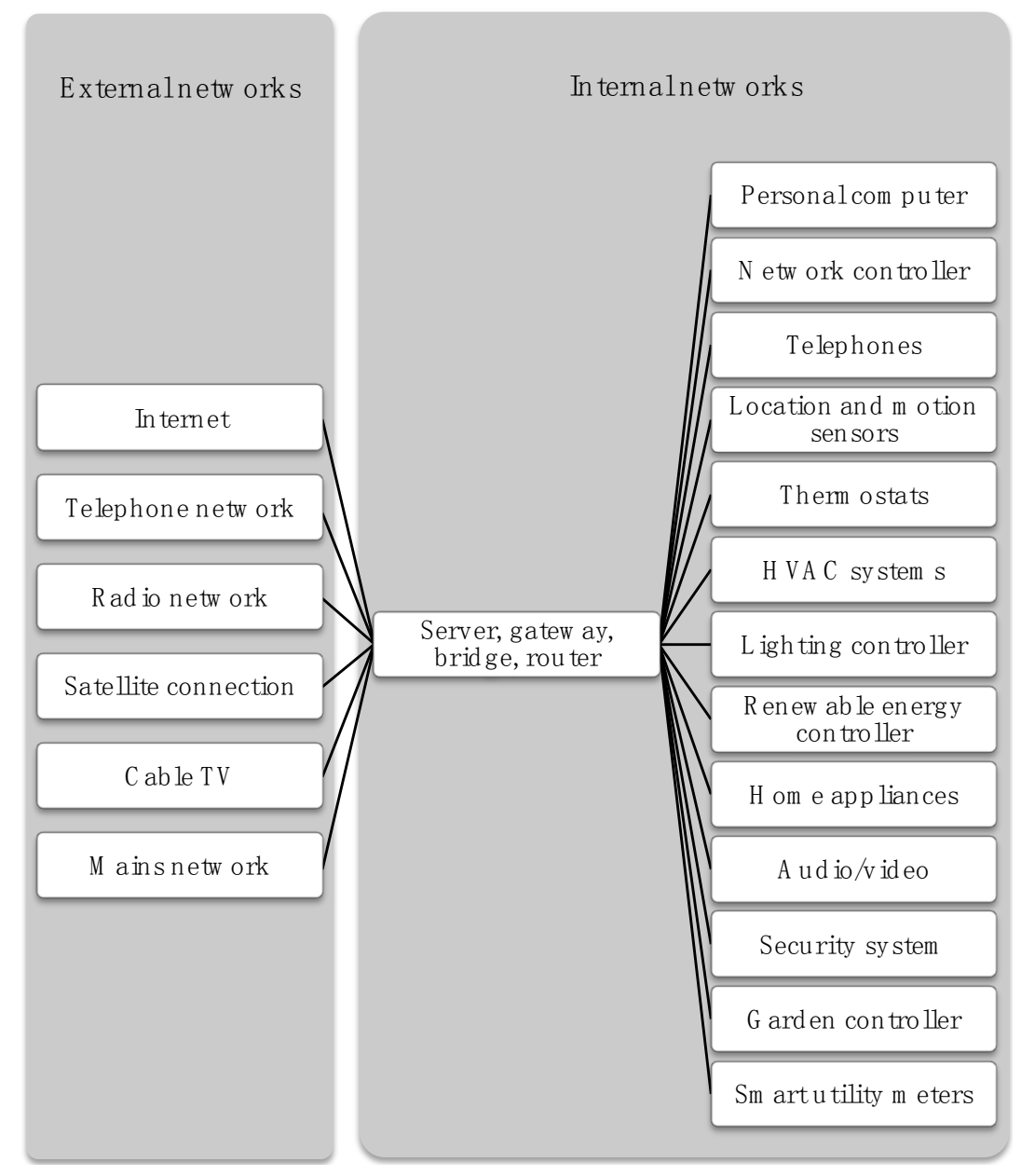

Figure 2. Top-level architecture of a typical smart home. Modified from reference [50]. 
Table 2. Comparison among the different integrated wireless technologies.

\begin{tabular}{|c|c|c|c|c|c|c|c|c|}
\hline IWT & Description and Main Features & $\begin{array}{c}\text { Max Transmission } \\
\text { Speed/Operation } \\
\text { Range }\end{array}$ & $\begin{array}{l}\text { Transmission } \\
\text { Distance }\end{array}$ & Standard & $\begin{array}{c}\text { Internet } \\
\text { Protocol (IP) } \\
\text { Support }\end{array}$ & $\begin{array}{c}\text { Adoption } \\
\text { Rate }\end{array}$ & Strengths & Reference \\
\hline 6LoWPAN & $\begin{array}{l}\text { (1) Its full name is IPv6 over Low-Power } \\
\text { Wireless Personal Area Networks; } \\
\text { (2) It is a networking technology that allows } \\
\text { IPv6 packets to be carried efficiently within } \\
\text { small link layer frames, such as those defined } \\
\text { by IEEE 802.15.4; } \\
\text { (3) It enables IEEE } 802.15 .4 \text { (IEEE* } \\
\text { subcommittee for low rate WPAN) and IPv6 } \\
\text { to work together in order to achieve IP } \\
\text { enabled low-power networks of small devices } \\
\text { including sensors, controllers etc.; } \\
\text { (4) The standard IETF RFC } 4944 \text { describes the } \\
\text { mechanism of combining IP and } \\
\text { WPAN technologies }\end{array}$ & $\begin{array}{l}250 \mathrm{kbps}, 2.4 \mathrm{GHz} ; \\
40 \mathrm{kbps}, 915 \mathrm{MHz} ; \\
20 \mathrm{kbps}, 868 \mathrm{MHz}\end{array}$ & Up to $200 \mathrm{~m}$ & $\begin{array}{l}\text { IETF RFC 4944; } \\
\text { IEEE 802.15.4 }\end{array}$ & IPv6 & Medium & $\begin{array}{l}\text { (1) Benefits of both IP } \\
\text { and Bluetooth; } \\
\text { (2) Low energy usage }\end{array}$ & {$[51,52]$} \\
\hline Bluetooth & $\begin{array}{l}\text { (1) It is wireless communications system used } \\
\text { to exchange data over short distances; } \\
\text { (2) It employs short-wave length radio } \\
\text { transmission in the Industrial, scientific and } \\
\text { medical (ISM) band ( } 2400-2480 \mathrm{MHz} \text { ); } \\
\text { (3) Its main features are low energy usage and } \\
\text { fast data exchange as well as } \\
\text { widespread availability }\end{array}$ & $\begin{array}{l}721 \text { kbps for v1; } \\
2.1 \text { Mbps for v2.0 + } \\
\text { EDR **; } \\
24 \text { Mbps for v3 + HS ***; } \\
25 \text { Mbps for } \mathrm{v} 4\end{array}$ & $10 \mathrm{~m}$ typical & IEEE 802.15 .1 & - & $\begin{array}{l}\text { Extremely } \\
\text { high }\end{array}$ & $\begin{array}{l}\text { (1) Ease of access; } \\
\text { (2) No configuration } \\
\text { requirement;Secure } \\
\text { connection }\end{array}$ & {$[53,54]$} \\
\hline DASH7 & $\begin{array}{l}\text { (1) It is an open source wireless network } \\
\text { protocol for sensors and actuators, which } \\
\text { operates in the } 433 \mathrm{MHz}, 868 \mathrm{MHz} \text { and } 915 \\
\text { MHz unlicensed ISM band/SRD band;It } \\
\text { provides multi-year battery life; } \\
\text { (2) It ranges of up to } 2 \mathrm{~km} \text {; } \\
\text { (3)It has low latency for connecting with } \\
\text { moving things; } \\
\text { (4) It has a very small open source } \\
\text { protocol stack } \\
\text { (5) It has AES 128-bit shared key } \\
\text { encryption support; } \\
\text { (6) It has a data transfer of up to } 167 \mathrm{kbit} / \mathrm{s} \text {; } \\
\text { (7) DASH7 Alliance Protocol is the name of } \\
\text { the technology promoted by the non-profit } \\
\text { consortium called the DASH7 Alliance }\end{array}$ & $200 \mathrm{kbps}$ & $\begin{array}{c}0-500 \mathrm{~m} \text { and } \\
0.3-1 \mathrm{~km}\end{array}$ & $\begin{array}{l}\text { ISO/IEC } \\
18000-7\end{array}$ & Yes & Medium & $\begin{array}{l}\text { (1) It penetrates concrete } \\
\text { and water; } \\
\text { (2) It transmits and receives } \\
\text { over very long ranges } \\
\text { without requiring a large } \\
\text { power draw on a battery }\end{array}$ & [55] \\
\hline
\end{tabular}


Table 2. Cont

\begin{tabular}{|c|c|c|c|c|c|c|c|c|}
\hline IWT & Description and Main Features & $\begin{array}{c}\text { Max Transmission } \\
\text { Speed/Operation } \\
\text { Range }\end{array}$ & $\begin{array}{l}\text { Transmission } \\
\text { Distance }\end{array}$ & Standard & $\begin{array}{l}\text { Internet } \\
\text { Protocol (IP) } \\
\text { Support }\end{array}$ & $\begin{array}{l}\text { Adoption } \\
\text { Rate }\end{array}$ & Strengths & Reference \\
\hline $\begin{array}{l}\text { EnOcean } \\
\text { Technology }\end{array}$ & $\begin{array}{l}\text { (1) It is an innovative energy harvesting } \\
\text { wireless technology with the smallest amount } \\
\text { of energy from their environment; } \\
\text { (2) It consists of wireless technology } \\
\text { components for self-powered wireless control, } \\
\text { signalling and monitoring of systems }\end{array}$ & $\begin{array}{l}\text { It is on the } 868.3 \text { or } \\
315 \mathrm{MHz} \text { frequency }\end{array}$ & $30 \mathrm{~m}$ (in-doors) & $\begin{array}{l}\text { ISO/IEC } \\
\text { 14543-3-1; IEEE } \\
802.15 .4\end{array}$ & Yes & Medium & $\begin{array}{l}\text { (1) Energy management } \\
\text { and highly efficient } \\
\text { energy storage; } \\
\text { (2) It uses wireless } \\
\text { standards optimized for } \\
\text { solutions with ultra-low } \\
\text { power consumption. }\end{array}$ & [56] \\
\hline GSM & $\begin{array}{l}\text { (1) Global system mobile (GSM/GPRS) is a } \\
\text { mobile phone communication that operates in } \\
\text { geographical cells. The sizes of these cells } \\
\text { depends on the required need for traffic } \\
\text { distribution and demand; } \\
\text { (2) It is better known as a mobile wireless } \\
\text { system and it operates at either } 900 \mathrm{MHz} \text { or } \\
1800 \mathrm{MHz} \text { frequency band }\end{array}$ & $270 \mathrm{kbps}$ & $\begin{array}{l}\text { Several } \\
\text { kilometers }\end{array}$ & $\begin{array}{l}\text { Gaussian } \\
\text { Minimum Shift } \\
\text { Keying (GMSK) }\end{array}$ & $\begin{array}{l}\text { Yes, static and } \\
\text { dynamic IP }\end{array}$ & $\begin{array}{l}\text { Widely } \\
\text { adopted }\end{array}$ & $\begin{array}{l}\text { (1) Low cost; } \\
\text { (2) High-quality signal; } \\
\text { (3) High compatibility }\end{array}$ & [57] \\
\hline MyriaNed & $\begin{array}{l}\text { (1) It is a self-organizing, gossiping wireless } \\
\text { sensor network (WSN) platform; } \\
\text { (2) It uses an epidemic communication style } \\
\text { based on standard radio broadcasting; } \\
\text { (3) It is inspired by biological processes where } \\
\text { many nodes (e.g., birds, ants, cells) operate in } \\
\text { large distributed systems (flocks, organized } \\
\text { colonies, organisms); } \\
\text { (4) Its technology is a decentralized system } \\
\text { based on bottom up approach, where the } \\
\text { behavior of a single element (node) will result } \\
\text { in emerging behavior of the } \\
\text { system (application) }\end{array}$ & $\begin{array}{l}2.4 \mathrm{GHz} \text { radio } \\
\text { frequency; } \\
868 \mathrm{MHz} \text { radio } \\
\text { frequency; } \\
\text { Other frequencies are } \\
\text { under development }\end{array}$ & Several meters & $\begin{array}{l}\text { MyriaNed } \\
\text { GOSSIP } \\
\text { protocol; MAC } \\
* * * * \text { protocol }\end{array}$ & Yes & $\begin{array}{l}\text { Medium/low: } \\
\text { the system is } \\
\text { developing }\end{array}$ & $\begin{array}{l}\text { (1) Low energy usage; } \\
\text { (2) Low cost; } \\
\text { (3) Scalable; } \\
\text { (4) Self-configuring }\end{array}$ & [58] \\
\hline $\begin{array}{l}\text { NeuRFon }^{\mathrm{TM}} \\
\text { Netform }\end{array}$ & $\begin{array}{l}\text { (1) It is a self-organizing wireless network for } \\
\text { low data rate, low-power fixed sensor nodes; } \\
\text { (2) The protocol utilizes a logical backbone } \\
\text { architecture through which data } \\
\text { communication between all the network } \\
\text { nodes are supported by hierarchical routing }\end{array}$ & $250 \mathrm{kbps}$ & $20 \mathrm{~m}$ & $\begin{array}{l}\text { IEEE 802.15.4; } \\
\text { MAC **** } \\
\text { protocol }\end{array}$ & - & Medium & $\begin{array}{l}\text { (1) Low data rate; } \\
\text { (2) Low energy usage }\end{array}$ & [59] \\
\hline RFID & $\begin{array}{l}\text { (1) Radio frequency identification (RFID) is a } \\
\text { system that transmits the objects identity } \\
\text { wirelessly by radio waves; } \\
\text { (2) It can be categorized based on its used } \\
\text { frequency range: low (124-135 KHz), high } \\
(13.56 \mathrm{MHz} \text { ) and ultra-high frequency } \\
(860-960 \mathrm{MHz})\end{array}$ & $\begin{array}{l}\text { Low 124-135 KHz; } \\
\text { High } 13.56 \mathrm{MHz} ; \\
\text { Ultra-high } \\
860-960 \mathrm{MHz}\end{array}$ & $\begin{array}{l}\text { Low } 30 \mathrm{~cm} \text {; } \\
\text { High } 1.5 \mathrm{~m} ; \\
\text { Ultra-high } \\
1-15 \mathrm{~m}\end{array}$ & $\begin{array}{l}\text { Various } \\
\text { standards }\end{array}$ & Yes & $\begin{array}{l}\text { Widely } \\
\text { adopted }\end{array}$ & $\begin{array}{l}\text { (1) Stable technology; } \\
\text { (2) Continue evolution; } \\
\text { (3) Open architectures } \\
\text { becoming increasingly } \\
\text { available }\end{array}$ & [60] \\
\hline
\end{tabular}


Table 2. Cont

\begin{tabular}{|c|c|c|c|c|c|c|c|c|}
\hline IWT & Description and Main Features & $\begin{array}{c}\text { Max Transmission } \\
\text { Speed/Operation } \\
\text { Range } \\
\end{array}$ & $\begin{array}{l}\text { Transmission } \\
\text { Distance }\end{array}$ & Standard & $\begin{array}{c}\text { Internet } \\
\text { Protocol (IP) } \\
\text { Support }\end{array}$ & $\begin{array}{l}\text { Adoption } \\
\text { Rate }\end{array}$ & Strengths & Reference \\
\hline UWB & $\begin{array}{l}\text { (1) It has recently attracted much attention as } \\
\text { an indoor short-range high-speed wireless } \\
\text { communication [36]; } \\
\text { (2) One of the most interesting characteristics } \\
\text { is that its bandwidth is over } 110 \text { Mbps (up to } \\
480 \text { Mbps), which can satisfy most of the } \\
\text { multimedia applications such as audio and } \\
\text { video delivery in home networking; } \\
\text { (3) It can also act as a wireless cable } \\
\text { replacement of high speed serial bus such as } \\
\text { USB } 2.0 \text { and IEEE } 1394\end{array}$ & $100 \mathrm{Mbps}$ & $10 \mathrm{~m}$ & $802.15 .3 a$ & Yes & Medium & $\begin{array}{l}\text { (1) Indoor short-range } \\
\text { high-speed; } \\
\text { (2) Its bandwidth satisfies } \\
\text { most of the multimedia } \\
\text { applications }\end{array}$ & [61] \\
\hline Wi-Fi & $\begin{array}{l}\text { (1) It is a very popular technology used in } \\
\text { HANs, mobile phones, personal computers } \\
\text { and many other electronic devices; } \\
\text { (2) Its main feature is the existing wide } \\
\text { support: almost every new electronic device, } \\
\text { be it a personal computer, laptop, game } \\
\text { console or a peripheral device, comes with } \\
\text { installed Wi-Fi technology; } \\
\text { (3) It is generally upper layer protocol with IP } \\
\text { being the most predominant protocol, } \\
\text { allowing communications over the internet } \\
\text { without needing a protocol translator }\end{array}$ & $300 \mathrm{Mbps}$ & $100 \mathrm{~m}$ & IEEE 802.11 & IPv6 & $\begin{array}{l}\text { Extremely } \\
\text { high }\end{array}$ & $\begin{array}{l}\text { High speed mature } \\
\text { standard }\end{array}$ & [62] \\
\hline WLAN & $\begin{array}{l}\text { (1) Wireless local area network (WLAN) } \\
\text { employs the spread spectrum technology, so } \\
\text { that users can occupy the same frequency } \\
\text { bands while causing minimal interference to } \\
\text { each other; } \\
\text { (2) Also known as Wireless Ethernet, it is able } \\
\text { to provide robust communications with low } \\
\text { latency and capable of point-to-point as well } \\
\text { as point-to-multi-point transmissions }\end{array}$ & $150 \mathrm{Mbps}$ & $250 \mathrm{~m}$ & IEEE 802.11 & IPv6 & $\begin{array}{l}\text { Extremely } \\
\text { high }\end{array}$ & $\begin{array}{l}\text { Low interference from } \\
\text { users }\end{array}$ & [63] \\
\hline
\end{tabular}


Table 2. Cont

\begin{tabular}{|c|c|c|c|c|c|c|c|c|}
\hline IWT & Description and Main Features & $\begin{array}{c}\text { Max Transmission } \\
\text { Speed/Operation } \\
\text { Range }\end{array}$ & $\begin{array}{l}\text { Transmission } \\
\text { Distance }\end{array}$ & Standard & $\begin{array}{l}\text { Internet } \\
\text { Protocol (IP) } \\
\text { Support }\end{array}$ & $\begin{array}{l}\text { Adoption } \\
\text { Rate }\end{array}$ & Strengths & Reference \\
\hline Z-Wave & $\begin{array}{l}\text { (1) It is a proprietary standard intended } \\
\text { exclusively for remote control applications in } \\
\text { residential and business areas; } \\
\text { (2) This protocol works at } 868 \mathrm{MHz} \text { in Europe } \\
\text { and } 908 \mathrm{MHz} \text { ISM band in USA; } \\
\text { (3) It has typically } 30 \text { min door range, which } \\
\text { extends up to } 100 \text { m outdoors; } \\
\text { (4) Mesh networking is employed in Z-Wave, } \\
\text { essentially meaning an unlimited range; } \\
\text { (5) The main advantages of this technology } \\
\text { comes from simple command structure, } \\
\text { freedom from household interference, } \\
\text { low-band width control medium and } \\
\text { IP support }\end{array}$ & $100 \mathrm{kbps}$ & $\begin{array}{l}30 \mathrm{~m} \text { indoor; } \\
100 \mathrm{~m} \text { outdoor }\end{array}$ & Proprietary & Yes & Medium & $\begin{array}{l}\text { No interference from } \\
\text { household devices }\end{array}$ & [64] \\
\hline ZigBee & $\begin{array}{l}\text { (1) It is a wireless mesh network that proved } \\
\text { to be very efficient and cost effective; } \\
\text { (2) It offers low data rate for Personal area } \\
\text { networks (PANs); } \\
\text { (3) It can be used broadly in device control, } \\
\text { reliable messaging, home and building } \\
\text { automation, consumer electronics, remote } \\
\text { monitoring, health care, and many other areas }\end{array}$ & $\begin{array}{l}250 \text { kbps }(2.4 \mathrm{GHz}) ; \\
40 \text { kbps }(915 \mathrm{MHz})\end{array}$ & $10-75 \mathrm{~m}$ & IEEE 802.15.4 & $\begin{array}{l}\text { IPv6 only in } \\
\text { SEP2 }\end{array}$ & $\begin{array}{l}\text { Widely } \\
\text { adopted }\end{array}$ & $\begin{array}{l}\text { Low cost, low power usage, } \\
\text { high number of nodes }\end{array}$ & {$[62,65,66]$} \\
\hline
\end{tabular}

IEEE *: Institute of Electrical and Electronics Engineers; EDR **: Enhanced Data Rate; HS ***: High Speed; MAC ***: Medium Access Control. 


\subsection{Home Energy Management}

Development of the home energy management system (HEMS) started due to the energy shortage and the effects of global warming. Since its first application in 1976 [67], it has become one of the most popular research topics. The HEMS allows the energy usage of a building to be managed and controlled automatically and helps reduce peak demand for electricity and users' electricity bills [41].

The number of HEMS installations is rising in areas of North America and Europe that have a high latitude, because of the number of hours of darkness each year. In those areas, the HEMS reduce quite significantly the total electricity demand: up to $30 \%$ of the electricity load takes place during peak hours. The peak load can be reduced by, on average, $30 \%$ and the operational cost of electricity by $23 \%[26,68,69]$.

In smart grids, the use of energy management systems has become a priority to distribute locally the energy generated by users according to the prices of the energy, which is regulated by daily rates. A future trend might be operating using specific hourly rates, i.e., real time pricing (RTP), time of use (ToU), inclining block rates (IBR), critical peak pricing (CPP) etc.

If this method is used, the HEMS will improve the number of products that customers could use to perform daily tasks such as viewing data on energy usage, controlling thermostats, and individual home appliances, looking at tips on ways to save energy, manage a profile for participation in demand-response programs, and viewing their account and billing information. According to LaMarche et al. [69] and Green Tech Media [70], all types of products available on the residential market can be divided into three categories (control devices, graphical user interfaces, and enabling technologies) that include the fundamental aspects summarized in Table 3.

Table 3. Descriptions and examples of HEMSs. Source: [69].

\begin{tabular}{|c|c|c|c|}
\hline Category & Technology & Description & Examples \\
\hline \multirow{3}{*}{ Control devices } & Centralized & $\begin{array}{l}\text { It allows communicating with } \\
\text { multiple appliances in the home } \\
\text { environment. The users can manage } \\
\text { them from a single location and } \\
\text { often using multiple inputs }\end{array}$ & $\begin{array}{l}\text { - Home automation (HA) systems; } \\
\text { - Whole-home lighting } \\
\text { - } \quad \text { Sentrol systems; } \\
\text { - }\end{array}$ \\
\hline & $\begin{array}{l}\text { Device/Appliance- } \\
\text { Level }\end{array}$ & $\begin{array}{l}\text { User controls a single device or } \\
\text { function and standalone control }\end{array}$ & $\begin{array}{l}\text { - } \quad \text { Lighting control with motion } \\
\text { sensors, dimmers, } \\
\text { remotes, scheduling; } \\
\text { - } \quad \text { Thermostats; } \\
\text { - } \quad \text { Smart plugs; } \\
\text { - } \quad \text { Smart power strips }\end{array}$ \\
\hline & $\begin{array}{l}\text { On-Board } \\
\text { (automated on } \\
\text { appliance level) }\end{array}$ & $\begin{array}{l}\text { Control functionality integrated in } \\
\text { the device }\end{array}$ & $\begin{array}{l}\text { - Smart appliances, e.g., that } \\
\text { respond to grid; } \\
\text { - Office equipment } \\
\text { power management; } \\
\text { - Smart light bulb }\end{array}$ \\
\hline \multirow{3}{*}{$\begin{array}{l}\text { Graphical User } \\
\text { Interfaces }\end{array}$} & $\begin{array}{l}\text { Home Energy } \\
\text { Display }\end{array}$ & $\begin{array}{l}\text { Stand-alone in home display; } \\
\text { often portable }\end{array}$ & \multirow{2}{*}{$\begin{array}{l}\text { Many HEDs on the market have } \\
\text { compatible web dashboards or are } \\
\text { able to connect to third } \\
\text { party freeware; } \\
\text { Utilities implementing smart } \\
\text { meters often provide their } \\
\text { customers with web dashboards }\end{array}$} \\
\hline & $\begin{array}{l}\text { Web } \\
\text { Dashboard/Portal }\end{array}$ & $\begin{array}{l}\text { Online interface accessible from any } \\
\text { Internet-enabled device }\end{array}$ & \\
\hline & $\begin{array}{l}\text { Smartphone } \\
\text { Application }\end{array}$ & $\begin{array}{l}\text { Device-specific interfaces for } \\
\text { iPhones, Android phones, } \\
\text { and others }\end{array}$ & $\begin{array}{l}\text { - Current products typically pull } \\
\text { information from a home energy } \\
\text { display and generates } \\
\text { processed data; }\end{array}$ \\
\hline
\end{tabular}


Table 3. Cont.

\begin{tabular}{|c|c|c|c|}
\hline Category & Technology & Description & Examples \\
\hline \multirow{3}{*}{$\begin{array}{l}\text { Enabling } \\
\text { Technologies }\end{array}$} & Sensing & $\begin{array}{l}\text { Acquisition of dynamic variables } \\
\text { within the home environment }\end{array}$ & $\begin{array}{ll}\text { - } & \text { Smart meters; } \\
\text { - } & \text { Temperature sensors; } \\
\text { - } & \text { Occupancy sensors }\end{array}$ \\
\hline & Communications & $\begin{array}{l}\text { Physical devices necessary to } \\
\text { support the network }\end{array}$ & $\begin{array}{ll}\text { - } & \text { Gateways; } \\
\text { - } & \text { Range extenders; } \\
\text { - } & \text { Home area networks }\end{array}$ \\
\hline & Communication Protocols & $\begin{array}{l}\text { Standards that allow individual } \\
\text { nodes within a network to } \\
\text { communicate }\end{array}$ & $\begin{array}{ll}\text { - } & \text { Insteon; } \\
\text { - } & \text { Z-wave; } \\
\text { - } & \text { ZigBee; } \\
\text { - } & \text { Others }\end{array}$ \\
\hline
\end{tabular}

The advantages of the HEMS are:

(i) The increased savings for both users and utilities providers;

(ii) A reduced peak-to-average ratio and peak loads;

(iii) They can include local energy production from renewable sources;

(iv) They allows the household to be inserted in a systemic context, as a separate local grid, and allow it to be connected to the outside world, i.e., creates a smart grid;

(v) They allow for historical comparisons of home energy usage.

The use of a centralized control function for the user interface, which includes a control for the use of appliances, is recommend and it would be useful to educate the end-users on how to use the integrated automated controls systems to avoid having automation that the end-users do not know to operate properly. Although, it would be necessary to develop a tailor-made user interface for a HEMS to work in smart homes, HEMS would enable the use of locally generated energy, the integration of energy storage, and an efficient connection with a smart grid. A comparison of the analyzed HEMS available on the market is presented in Table 4 .

Table 4. Comparison of the analyzed HEMS.

\begin{tabular}{|c|c|c|c|c|}
\hline Product Name & Main Features & Strengths & Weaknesses & Reference \\
\hline CISCO & $\begin{array}{l}\text { It provides energy } \\
\text { management to industry } \\
\text { of all sizes and homes. } \\
\text { The service, called Cisco } \\
\text { Energy Optimization } \\
\text { Services, uses advanced } \\
\text { technology to maximize } \\
\text { energy and cost savings } \\
\text { across the network } \\
\text { and datacenters; }\end{array}$ & $\begin{array}{l}\text { (1) Demand-response programs: } \\
\text { utilities can significantly } \\
\text { improve grid capacity and asset } \\
\text { usage at peak times by reducing } \\
\text { the load on generation } \\
\text { and distribution; } \\
\text { (2) The pricing programs, such } \\
\text { as critical-peak and time-of-day, } \\
\text { for reducing and shifting the } \\
\text { power demand have } \\
\text { been embedded }\end{array}$ & $\begin{array}{l}\text { The system has not } \\
\text { been integrated in } \\
\text { the CISCO } \\
\text { Connected Grid } \\
\text { Energy } \\
\text { Management } \\
\text { system }\end{array}$ & [71] \\
\hline
\end{tabular}


Table 4. Cont.

\begin{tabular}{|c|c|c|c|c|}
\hline Product Name & Main Features & Strengths & Weaknesses & Reference \\
\hline DigitalSTROM & $\begin{array}{l}\text { It is a system that } \\
\text { connects all home } \\
\text { electronic devices } \\
\text { through the existing } \\
\text { power lines. It includes a } \\
\text { control system and } \\
\text { smart metering }\end{array}$ & $\begin{array}{l}\text { (1) The system works using the } \\
\text { existing electric power lines of } \\
\text { the house; } \\
\text { (2) The components of the } \\
\text { system are largely invisible and } \\
\text { they could be applied on any } \\
\text { equipment of the house that } \\
\text { works with electricity; } \\
\text { (3) There are many apps } \\
\text { compatible with the system }\end{array}$ & $\begin{array}{l}\text { (1) The system } \\
\text { works well only } \\
\text { with } \\
\text { dedicated apps; } \\
\text { (2) The system } \\
\text { cannot be used for } \\
\text { managing the } \\
\text { energy of an } \\
\text { entire district }\end{array}$ & [72] \\
\hline Dreamwatts ${ }^{\circledR}$ & $\begin{array}{l}\text { It is a web-enabled, } \\
\text { user-friendly HEMS for } \\
\text { monitoring and } \\
\text { controlling the energy } \\
\text { usages of buildings }\end{array}$ & $\begin{array}{l}\text { (1) The system is open source } \\
\text { and accessible from everywhere; } \\
\text { (2) The system helps to } \\
\text { demonstrate the importance of } \\
\text { access to energy information; } \\
\text { (3) The system has user-friendly } \\
\text { interface, low cost monitoring } \\
\text { and control system; } \\
\text { (4) It provides the lowest cost of } \\
\text { ownership of any product on } \\
\text { the market }\end{array}$ & $\begin{array}{l}\text { The system is an } \\
\text { energy monitoring } \\
\text { tool that doesn't } \\
\text { allow any changes } \\
\text { by the users }\end{array}$ & [73] \\
\hline e-GOTHAM & $\begin{array}{l}\text { It is an open smart-grid } \\
\text { system that allows users } \\
\text { to manage components } \\
\text { within a micro-grid, and } \\
\text { to operate in } \\
\text { collaboration with the } \\
\text { overall smart grid }\end{array}$ & $\begin{array}{l}\text { (1) The system has multiple } \\
\text { local controllers; } \\
\text { (2) It offers communication } \\
\text { among producers, users, a } \\
\text { common information model, } \\
\text { databases and algorithms in } \\
\text { order to coordinate the } \\
\text { appliances via the user } \\
\text { applications }\end{array}$ & $\begin{array}{l}\text { (1) The system has } \\
\text { only been tested in } \\
\text { a large scale living } \\
\text { lab for Smart Grid } \\
\text { activities in the } \\
\text { community of } \\
\text { Steinkjer (Norway); } \\
\text { (2) The system } \\
\text { needs to become } \\
\text { more flexible and } \\
\text { scalable in order to } \\
\text { be used in } \\
\text { industrial or } \\
\text { tertiary sector }\end{array}$ & [74] \\
\hline EmonCMS & $\begin{array}{l}\text { It is a free app for } \\
\text { processing, logging and } \\
\text { visualizing energy usage, } \\
\text { temperature and } \\
\text { environmental data }\end{array}$ & $\begin{array}{l}\text { (1) The users can have full } \\
\text { control of the energy data; } \\
\text { (2) The app can be install on a } \\
\text { private server or on the } \\
\text { hosted service; } \\
\text { (3) Input processing allows for } \\
\text { conversion and processing } \\
\text { before storage. There are over } 23 \\
\text { different input processes from } \\
\text { simple calibration to power } \\
\text { data, and can be represented } \\
\text { with an histogram; } \\
\text { (4) Zoom through large data-set, } \\
\text { compare multiple datasets by } \\
\text { using the multi-graph } \\
\text { visualization builder; } \\
\text { (5) The system could be } \\
\text { installed directly by the users }\end{array}$ & $\begin{array}{l}\text { The system doesn't } \\
\text { allow any remote } \\
\text { control for } \\
\text { managing and } \\
\text { controlling the } \\
\text { energy of the house } \\
\text { as well as to create } \\
\text { a users' schedule in } \\
\text { order to setting the } \\
\text { turn on/off time of } \\
\text { the home } \\
\text { equipment }\end{array}$ & [75] \\
\hline
\end{tabular}


Table 4. Cont.

\begin{tabular}{|c|c|c|c|c|}
\hline Product Name & Main Features & Strengths & Weaknesses & Reference \\
\hline $\begin{array}{l}\text { Energy Team's } \\
\text { Energy Data } \\
\text { Collector Tool }\end{array}$ & $\begin{array}{l}\text { (1) The tool is } \\
\text { constituted of (i) an } \\
\text { integrated web server for } \\
\text { the configuration of the } \\
\text { system and data analysis; } \\
\text { and (ii) a gateway to } \\
\text { collect, store and send } \\
\text { data to a the server; } \\
\text { (2) It visualizes energy } \\
\text { usage trough a web } \\
\text { application }\end{array}$ & $\begin{array}{l}\text { (1) It can manage hundreds of } \\
\text { sensors and up to } 1600 \\
\text { measures; } \\
\text { (2) Direct Wi-Fi connection to } \\
\text { the device even with no web } \\
\text { platforms available; } \\
\text { (3) HTML } 5 \text { web application, } \\
\text { optimized for mobile devices } \\
\text { that automatically adapts to the } \\
\text { equipment used; } \\
\text { (4) } 8 \text { GB of local storage memory }\end{array}$ & $\begin{array}{l}\text { (1) The system is } \\
\text { an energy } \\
\text { monitoring tool } \\
\text { that doesn't allow } \\
\text { any direct changes } \\
\text { by the users; } \\
\text { (2) Design of } \\
\text { components } \\
\text { optimized for } \\
\text { industrial } \\
\text { applications and } \\
\text { not for home } \\
\text { installation; } \\
\text { (3) A touchscreen is } \\
\text { not available to } \\
\text { enhance the user's } \\
\text { experience }\end{array}$ & [76] \\
\hline $\begin{array}{c}\text { Google } \\
\text { PowerMeter }\end{array}$ & $\begin{array}{l}\text { It is an energy } \\
\text { monitoring utility } \\
\text { including the } \\
\text { visualization of energy } \\
\text { usage, the possibility to } \\
\text { share information and } \\
\text { energy saving tips }\end{array}$ & $\begin{array}{l}\text { (1) The system is open source } \\
\text { and accessible from everywhere; } \\
\text { (2) The system helps to } \\
\text { demonstrate the importance of } \\
\text { access to energy information; } \\
\text { (3) The system allows to } \\
\text { personalize recommendations in } \\
\text { order to save energy }\end{array}$ & $\begin{array}{l}\text { (1) The system is an } \\
\text { energy monitoring } \\
\text { tool that doesn't } \\
\text { allow any changes } \\
\text { by the users; } \\
\text { (2) The system } \\
\text { need more } \\
\text { development }\end{array}$ & [77] \\
\hline Savant & $\begin{array}{l}\text { The Savant HEMS } \\
\text { allows setting and } \\
\text { controlling the energy } \\
\text { usages of the home from } \\
\text { a GUI on electronic } \\
\text { devices }\end{array}$ & $\begin{array}{l}\text { (1) The system permits the users } \\
\text { to monitor energy usage and } \\
\text { production in real time, } \\
\text { including historical data of } \\
\text { multiple energy management } \\
\text { devices; } \\
\text { (2) Users can reduce energy } \\
\text { usage and costs by controlling } \\
\text { how and when specific devices } \\
\text { use power-particularly during } \\
\text { peak pricing or load periods }\end{array}$ & $\begin{array}{l}\text { (1) This system } \\
\text { requires } \\
\text { professional } \\
\text { installation; } \\
\text { (2) The company } \\
\text { does not offer } \\
\text { technical support } \\
\text { of any kind }\end{array}$ & [78] \\
\hline SMARTHEMS ${ }^{\mathrm{TM}}$ & $\begin{array}{l}\text { Panasonic has developed } \\
\text { its own HEMS. It uses } \\
\text { Artificial Intelligence } \\
\text { and Smart Energy } \\
\text { Gateway (AiSEG) to } \\
\text { manage energy } \\
\text { generation, storage and } \\
\text { savings equipment }\end{array}$ & $\begin{array}{l}\text { (1) The system allows to } \\
\text { promote energy savings by } \\
\text { visualizing energy usages. It } \\
\text { makes the flow of energy } \\
\text { throughout the entire home } \\
\text { visible by exchanging } \\
\text { information with home } \\
\text { appliances; } \\
\text { (2) By using smartphone, TV, } \\
\text { and other equipment, residents } \\
\text { can check the energy used by } \\
\text { each home appliance and in } \\
\text { each room }\end{array}$ & $\begin{array}{l}\text { The system has not } \\
\text { been integrated in } \\
\text { a smart grid yet }\end{array}$ & [79] \\
\hline
\end{tabular}


Table 4. Cont.

\begin{tabular}{|c|c|c|c|c|}
\hline Product Name & Main Features & Strengths & Weaknesses & Reference \\
\hline $\begin{array}{l}\text { The Energy } \\
\text { Navigator } \\
\text { platform }\end{array}$ & $\begin{array}{l}\text { (1) It is a web-based } \\
\text { platform of a building } \\
\text { management system; } \\
\text { (2) It automatically } \\
\text { creates reports to inform } \\
\text { other users about the } \\
\text { current system status, } \\
\text { and potential } \\
\text { performance issues of } \\
\text { the building }\end{array}$ & $\begin{array}{l}\text { (1) It allows monitoring and } \\
\text { specify the behavior of a } \\
\text { building management system; } \\
\text { (2) The user will be able to } \\
\text { create custom analyses for the } \\
\text { monitored building; } \\
\text { (3) The platform was designed } \\
\text { for multiuser access (data } \\
\text { import, preprocessing, analysis } \\
\text { reporting and specification); } \\
\text { (4) It establishes the concept of } \\
\text { templates for every artifact: an } \\
\text { user can specify his/her } \\
\text { knowledge once at the } \\
\text { beginning and use the templates } \\
\text { easily for every building that } \\
\text { he/she operates or manages }\end{array}$ & $\begin{array}{l}\text { Some function are } \\
\text { more suitable for } \\
\text { energy expert: for } \\
\text { example they can } \\
\text { use the platform to } \\
\text { visualize the } \\
\text { imported data with } \\
\text { multiple plot types, } \\
\text { e.g. line plots, } \\
\text { scatter plots or } \\
\text { carpet plots }\end{array}$ & [80] \\
\hline
\end{tabular}

\subsection{Smart Home Micro-Computers}

Smart Home Micro-Computers (SHMC) are small-sized computers that are connected to other devices in order to automatize and control the whole smart home system. They consist in a microcontroller with complementary components that facilitate programming and incorporation into other circuits. An important aspect is their standard connectors, which lets users be connected to a central processing unit (CPU) board to a variety of interchangeable add-on modules known as shields. They allow the users make interactive projects and applications with the environment by using multiple extensible connectors and by receiving inputs from many sensors and affect its surrounding by controlling lights or other actuators.

In literature, there are some examples of applications where SHMCs have been combined with wireless sensors to create home automation systems to monitor and control home appliances [81].

The strengths and weaknesses of each SHMC have been summarized in Table 5.

\subsection{Home Automation Systems}

Home Automation (HA) provides an intelligent interface that monitors and learns the users' habits and might anticipate and facilitate their movements. HA can make life easier and more comfortable or provide some energy efficiency savings by interacting with users remotely [82].

HA provides part of the system for managing the smart home. However, the HA system would need to be combined with non-automated devices for user interaction. For example, using only HA systems would not provide users with the ability to adjust their energy usage. But provided that, feedback is given to end-users based on the control activities performed as part of the smart home automation system. Such technology could well be included into an intelligent system that saves energy and improves thermal and visual comfort in the home by implementing both short-term and long-term thermal and visual discomfort indices $[83,84]$. Some of the most adopted HA systems available on the market are described in Table 6. 
Table 5. Strengths and weaknesses of the analyzed SHMCs.

\begin{tabular}{|c|c|c|c|c|}
\hline Product Name & Main Features & Strengths & Weaknesses & Reference \\
\hline Arduino & $\begin{array}{l}\text { (1) It is an open-source electronics platform } \\
\text { equipped with hardware and software; } \\
\text { (2) It senses the environment by receiving } \\
\text { inputs from many sensors, and affects its } \\
\text { surroundings by controlling lights, motors, } \\
\text { and other actuators }\end{array}$ & $\begin{array}{l}\text { (1) High flexibility and compatibility with the different kind } \\
\text { of sensors; } \\
\text { (2) It is intended for anyone making interactive projects }\end{array}$ & \multirow{5}{*}{$\begin{array}{l}\text { (1) All these systems require the user to } \\
\text { have some technical background and } \\
\text { electronics basics; } \\
\text { (2) It also requires time to be learned } \\
\text { and become expert in assembling and } \\
\text { using it. However, many tutorials and } \\
\text { detailed information about their } \\
\text { assembly and use are free available } \\
\text { on line; } \\
\text { (3) Another barrier is constituted by } \\
\text { their commercial price that can also } \\
\text { reach thousands of euros }\end{array}$} & [85] \\
\hline Banana Pi & $\begin{array}{l}\text { (1) It is a single-board computer; } \\
\text { (2) It can serve as a platform to make many } \\
\text { applications for different purposes }\end{array}$ & $\begin{array}{l}\text { (1) It targets to be a cheap, small and flexible enough } \\
\text { computer for daily life; } \\
\text { (2) It is built with ARM Cortex-A7 Dual-core CPU and } \\
\text { Mali400MP2 GPU and open source software; } \\
\text { (3) Most of common extension accessories Including LCD } \\
\text { panel, touch screen, camera module, UART console and } \\
\text { GPIO control pins are accessible from Banana Pi on-board } \\
\text { connectors and headers }\end{array}$ & & {$[86]$} \\
\hline BeagleBone Black & $\begin{array}{l}\text { (1) It is an open hardware micro-computer } \\
\text { similar to both Raspberry Pi and Banana Pi; } \\
\text { (2) It has a MR Cortex-A8 processor. It is } \\
\text { equipped with Ubuntu and Android; } \\
\text { (3) It is an open hardware, } \\
\text { community-supported embedded computer } \\
\text { for developers and hobbyists }\end{array}$ & $\begin{array}{l}\text { (1) High flexibility and compatibility with the different kind } \\
\text { of sensors; } \\
\text { (2) It is intended for anyone making interactive projects }\end{array}$ & & [87] \\
\hline Raspberry Pi & $\begin{array}{l}\text { It is a capable credit-card sized computer } \\
\text { that allows developing electronics projects }\end{array}$ & $\begin{array}{l}\text { (1) Ability to interact with the outside world, and has been } \\
\text { used in a wide array of digital maker projects, from music } \\
\text { machines and parent detectors to weather stations and } \\
\text { tweeting birdhouses with infra-red cameras; } \\
\text { (2) Could be used by people of all ages; } \\
\text { (3) Its challenge is to be used by people of all ages to explore } \\
\text { computing and to learn how to program in languages like } \\
\text { Scratch and Python and how to manipulate the electronic } \\
\text { world around them }\end{array}$ & & {$[88]$} \\
\hline $\begin{array}{l}\text { Libelium } \\
\text { Waspmote }\end{array}$ & $\begin{array}{l}\text { (1) It is an advanced mote for Wireless sensor } \\
\text { networks (WSN); } \\
\text { (2) It allows a total control over the hardware } \\
\text { devices. It could be connected with any kind } \\
\text { of sensor }\end{array}$ & $\begin{array}{l}\text { (1) It is robust and waterproof; } \\
\text { (2) It supports the following protocols: ZigBee, Wi-Fi, } \\
\text { LoRaWAN, LoRa, Sigfox; } \\
\text { (3) It has a graphical and intuitive programming interface }\end{array}$ & & [89] \\
\hline
\end{tabular}


Table 6. Features, strengths, and weakness of the analyzed HA systems.

\begin{tabular}{|c|c|c|c|c|}
\hline Product Name & Main Features & Strengths & Weaknesses & Reference \\
\hline $\begin{array}{l}\text { British Gas Smarter } \\
\text { living \& Energy } \\
\text { saving_Smart meters }\end{array}$ & $\begin{array}{l}\text { It is a smart home energy monitoring and } \\
\text { controlling system developed by British } \\
\text { Gas for their customers in order to keep a } \\
\text { better control of the energy bills }\end{array}$ & $\begin{array}{l}\text { (1) It allows users to interact with home appliances } \\
\text { and works with a smart energy monitor that can } \\
\text { be placed anywhere in the home; } \\
\text { (2) It shows the used energy, gas and electricity, as } \\
\text { well as its cost }\end{array}$ & $\begin{array}{l}\text { It is a system developed by the British Gas } \\
\text { company and therefore it is linked to } \\
\text { a contract }\end{array}$ & [90] \\
\hline $\begin{array}{l}\text { Control4Home } \\
\text { Automation }\end{array}$ & $\begin{array}{l}\text { It is a HA system that allows the products } \\
\text { and devices that the users already have } \\
\text { and use every day, work together }\end{array}$ & $\begin{array}{l}\text { (1) Compatible with any other smart technology; } \\
\text { (2) User-friendly control by a dedicated app }\end{array}$ & $\begin{array}{l}\text { (1) The system allows the users to control } \\
\text { lights, audio and security in the house, but } \\
\text { not monitoring the energy usage } \\
\text { and production; } \\
\text { (2) The system must be installed } \\
\text { professionally by an authorized dealer; } \\
\text { (3) It works only with internet connection } \\
\text { and only with families of peripherals that are } \\
\text { compatible with the controllers in this } \\
\text { system are Bluetooth, Wi-Fi, KNX, Z-Wave } \\
\text { and ZigBee; } \\
\text { (4) It offers limited mobile access } \\
\text { functionality with its base system setup; } \\
\text { (5) The Help \& Support section of the system } \\
\text { is poorly performed }\end{array}$ & [91] \\
\hline $\begin{array}{l}\text { Creston Home } \\
\text { Automation \& } \\
\text { Entertainment }\end{array}$ & $\begin{array}{l}\text { Complete control of home appliances: } \\
\text { turn on TVs, lights, adjust thermostats, } \\
\text { fish tank or sauna, etc. }\end{array}$ & $\begin{array}{l}\text { (1) The simplicity of the system and the } \\
\text { user-friendly GUI; } \\
\text { (2) It is fully compatible with media players and } \\
\text { with home automation peripherals; } \\
\text { (3) Customers' service can support the users all the } \\
\text { time. Moreover, the user manual, FAQs, email } \\
\text { support, phone support and tutorials are available }\end{array}$ & $\begin{array}{l}\text { (1) The system allows the users to control } \\
\text { lights, audio and security in the house, but } \\
\text { not monitoring the energy usages } \\
\text { and production; } \\
\text { (2) Many of the peripherals are specifically } \\
\text { designed to work with Crestron } \\
\text { hardware controllers; } \\
\text { (3) The home automation system installation } \\
\text { must be set by professionals. Only after the } \\
\text { installation, the users can add } \\
\text { compatible devices; } \\
\text { (4) It does not have a live chat support option } \\
\text { or a user forum }\end{array}$ & [92] \\
\hline
\end{tabular}


Table 6. Cont.

\begin{tabular}{|c|c|c|c|c|}
\hline Product Name & Main Features & Strengths & Weaknesses & Reference \\
\hline $\begin{array}{l}\text { General Electric } \\
\text { Brillion Technology }\end{array}$ & $\begin{array}{l}\text { It allows the user to interact with their } \\
\text { smart home appliances using } \\
\text { smartphones }\end{array}$ & $\begin{array}{l}\text { It allows the user to monitor and control } \\
\text { appliances anytime, anywhere with a } \\
\text { smartphone app }\end{array}$ & $\begin{array}{l}\text { (1) It only works with General } \\
\text { Electric appliances; } \\
\text { (2) It is closed sourced }\end{array}$ & [93] \\
\hline HomeSeer HS3 & $\begin{array}{l}\text { It is a home HA system relatively easy to } \\
\text { use, but it takes time to master. It's highly } \\
\text { compatible with a variety of } \\
\text { home-control technologies and gives a } \\
\text { wide range of software compatibility } \\
\text { as well }\end{array}$ & $\begin{array}{l}\text { (1) Compatible with a variety of others systems } \\
\text { and programs; } \\
\text { (2) Online store available; } \\
\text { (3) It is compatible with the most popular } \\
\text { operating systems; } \\
\text { (4) The software gives you the option to create } \\
\text { simple or complex programs to help you get the } \\
\text { level of customization you desire for your smart } \\
\text { home. These programs can activate automatically, } \\
\text { manually and even using voice control; } \\
\text { (5) It is offers a strong customer support such as } \\
\text { video tutorials, telephone support and live chat, as } \\
\text { well as user manual and an online knowledgebase } \\
\text { and active community forum; (6) The system } \\
\text { works also without internet connection }\end{array}$ & $\begin{array}{l}\text { (1) It does not offer a home security } \\
\text { monitoring subscription; } \\
\text { (2) The Pro version requires an } \\
\text { extra payment; } \\
\text { (3) It doesn't support Bluetooth, KNX and } \\
\text { ZigBee control technologies }\end{array}$ & [94] \\
\hline $\begin{array}{l}\text { Honda Smart } \\
\text { Home US }\end{array}$ & $\begin{array}{l}\text { It is a hardware and software system that } \\
\text { monitors, controls and optimizes } \\
\text { electrical generation and usage } \\
\text { throughout the home micro-grid }\end{array}$ & $\begin{array}{l}\text { (1) The HA system stores solar energy generated } \\
\text { during the day for use at night, when household } \\
\text { demand typically peaks and electric vehicles are } \\
\text { usually charged; } \\
\text { (2) Capability of 'listening' to the grid to ensure } \\
\text { only draws power at the most } \\
\text { carbon-efficient times; } \\
\text { (3) Solar energy and plug-in electric vehicles can } \\
\text { join forces to provide zero carbon living } \\
\text { and mobility }\end{array}$ & $\begin{array}{l}\text { It is not compatible with other smart } \\
\text { technologies systems }\end{array}$ & [95] \\
\hline $\begin{array}{l}\text { iHome or Apple } \\
\text { HomeKit }\end{array}$ & $\begin{array}{l}\text { It has not been presented yet, but Apple } \\
\text { has announced that the system will be } \\
\text { released along with IOS8. However, } \\
\text { several iHome products are already } \\
\text { available in the market }\end{array}$ & $\begin{array}{l}\text { (1) It would use the location and the movements' } \\
\text { data from devices using GPS technology to } \\
\text { anticipate occupants' upcoming actions by } \\
\text { providing an intelligent reaction; } \\
\text { (2) A central hub device will allow connecting all } \\
\text { the home appliances }\end{array}$ & $\begin{array}{l}\text { (1) It has not been available on the } \\
\text { market yet; } \\
\text { (2) It only works with Whirlpool appliances; } \\
\text { (3) It is closed sourced }\end{array}$ & [96] \\
\hline
\end{tabular}


Table 6. Cont

\begin{tabular}{|c|c|c|c|c|}
\hline Product Name & Main Features & Strengths & Weaknesses & Reference \\
\hline Iris & $\begin{array}{l}\text { It is a simple, customizable smart home } \\
\text { management system by connecting with } \\
\text { compatible smart devices through a } \\
\text { single app }\end{array}$ & $\begin{array}{l}\text { The system is easy to control and has great } \\
\text { software compatibility }\end{array}$ & $\begin{array}{l}\text { (1) It does not interact with media players; } \\
\text { (2) It does not natively support Wi-Fi; } \\
\text { (3) The basic plan does not allow advanced } \\
\text { control to create rules and programs } \\
\text { across devices }\end{array}$ & [97] \\
\hline KNX & $\begin{array}{l}\text { It is an intelligent home and building } \\
\text { control that enables the combination of } \\
\text { different technologies and systems }\end{array}$ & $\begin{array}{l}\text { (1) It is a worldwide open standard; } \\
\text { (2) It is a flexible system able to combine different } \\
\text { technologies, appliances and systems from } \\
\text { different manufacturers within one system }\end{array}$ & The system is expensive & [98] \\
\hline LG Smart Thinq ${ }^{\mathrm{TM}}$ & $\begin{array}{l}\text { It is a HA system constituted by all the } \\
\text { home appliances that can communicate } \\
\text { each other }\end{array}$ & $\begin{array}{l}\text { (1) It allows user to monitor and control appliances } \\
\text { anytime, anywhere with a smartphone app; } \\
\text { (2) It provides personal suggestions customized to } \\
\text { the users habits, lifestyle and schedule to save } \\
\text { energy and improve efficiency } \\
\text { (3) The system communicates with the customers } \\
\text { center or transmits data over Wi-Fi to the } \\
\text { smartphone app for quick and easy diagnosis and } \\
\text { solutions in case of malfunctioning }\end{array}$ & $\begin{array}{l}\text { (1) It only works with LG appliances; } \\
\text { (2) It is closed sourced }\end{array}$ & [99] \\
\hline LonWorks & $\begin{array}{l}\text { LonWorks is a standard network in } \\
\text { buildings market with a number of } \\
\text { Building Automation Systems suppliers } \\
\text { standardizing on LON including Siemens } \\
\text { Building Systems and Honeywell }\end{array}$ & $\begin{array}{l}\text { (1) LonWorks is a standard technology for many of } \\
\text { the global standards organizations including } \\
\text { ASHRAE, IEEE, ANSI, SEMI and others; } \\
\text { (2) It is used for the automation of various } \\
\text { functions within buildings such as lighting } \\
\text { and HVAC }\end{array}$ & $\begin{array}{l}\text { It was mostly applied in commercial } \\
\text { buildings because its slow development } \\
\text { during the last few years }\end{array}$ & [100] \\
\hline Nexia & $\begin{array}{l}\text { The system works to monitor and } \\
\text { improve home energy usage patterns and } \\
\text { by integrating security components such } \\
\text { as security cameras, entry sensors and } \\
\text { door locks }\end{array}$ & $\begin{array}{l}\text { (1) It is easy to use given its relatively few features; } \\
\text { (2) It does not require professional help to install, } \\
\text { unless the users use one of the thermostats system } \\
\text { controller coupled with the system }\end{array}$ & $\begin{array}{l}\text { (1) The system does not support peripherals } \\
\text { other than Z-Wave; } \\
\text { (2) The system does not work with window } \\
\text { shading, such as blind and curtain motors, or } \\
\text { home theater systems; } \\
\text { (3) The system does not offer any } \\
\text { compatibility with other smart home } \\
\text { control technologies }\end{array}$ & [101] \\
\hline
\end{tabular}


Table 6. Cont

\begin{tabular}{|c|c|c|c|c|}
\hline Product Name & Main Features & Strengths & Weaknesses & Reference \\
\hline OpenHAB & $\begin{array}{l}\text { Easy integration with different } \\
\text { HA systems }\end{array}$ & $\begin{array}{l}\text { (1) The system is fully open source; } \\
\text { (2) No remote access is possible, if it is not desired; } \\
\text { (3) Everything works nicely within the intranet } \\
\text { and does not even require an Internet connection; } \\
\text { (4) The system is easily extensible to integrate } \\
\text { new devices; } \\
\text { (5) It can be run on any device that is capable of } \\
\text { running a Java virtual machine }\end{array}$ & $\begin{array}{l}\text { The system allows the users to control lights, } \\
\text { audio and security in the house, but not } \\
\text { monitoring the energy usage and production }\end{array}$ & [102] \\
\hline $\begin{array}{l}\text { Panasonic smart } \\
\text { appliance }\end{array}$ & $\begin{array}{l}\text { It is a HA system constituted by all the } \\
\text { home appliances that can communicate } \\
\text { each other }\end{array}$ & $\begin{array}{l}\text { It allows the user to control and manage their } \\
\text { smart appliances and power usage. They can be } \\
\text { remotely controlled and set on pause when energy } \\
\text { costs are high }\end{array}$ & $\begin{array}{l}\text { (1) It only works with Panasonic appliances; } \\
\text { (2) It is closed sourced }\end{array}$ & [103] \\
\hline Samsung SmartThings & $\begin{array}{l}\text { (1) It is a complete home monitoring and } \\
\text { security solution; } \\
\text { (2) It has to be coupled with a } \\
\text { Hub system }\end{array}$ & $\begin{array}{l}\text { The system gives you several ways to take control } \\
\text { of your smart home }\end{array}$ & $\begin{array}{l}\text { (1) The use of the app helps the system to } \\
\text { stay simple, but also make remote access } \\
\text { using a PC or Mac impossible; } \\
\text { (2) It does not support home audio } \\
\text { functionality, as well as voice control or } \\
\text { home security monitoring features }\end{array}$ & [104] \\
\hline Staples Connect & $\begin{array}{l}\text { It allows to connect appliances and } \\
\text { systems like lighting, heating and } \\
\text { air-conditioning, and even window } \\
\text { shading may be all controlled using one } \\
\text { of the dedicated app }\end{array}$ & $\begin{array}{l}\text { (1) The system is compatible with many } \\
\text { peripherals; } \\
\text { (2) It also has a security control; } \\
\text { (3) It has a strong technical support services such } \\
\text { as email, live chat and telephone, user forum } \\
\text { and FAQs; } \\
\text { (4) The system is principally available online }\end{array}$ & $\begin{array}{l}\text { (1) It does not support legacy HA protocols; } \\
\text { (2) It does not have a user manual; } \\
\text { (3) It is not compatible with home } \\
\text { theater systems; } \\
\text { (4) It does not support control technologies } \\
\text { like Insteon, KNX, UPB or X10 }\end{array}$ & [105] \\
\hline UPnP & $\begin{array}{l}\text { It is defined as universal architecture for } \\
\text { pervasive peer-to-peer network } \\
\text { connectivity of intelligent appliances, } \\
\text { devices and computers }\end{array}$ & $\begin{array}{l}\text { (1) Universal means that no device drivers are } \\
\text { required, but only common protocols are used; } \\
\text { (2) It allows true plug-and-play compatibility with } \\
\text { all UPnP enabled devices }\end{array}$ & $\begin{array}{l}\text { It could cause heavy network traffic. Every } \\
\text { device will communicate with any other } \\
\text { device on the network, and in such ways } \\
\text { slow the network down (depends on } \\
\text { the bandwidth) }\end{array}$ & {$[106]$} \\
\hline
\end{tabular}


Table 6. Cont

\begin{tabular}{|c|c|c|c|c|}
\hline Product Name & Main Features & Strengths & Weaknesses & Reference \\
\hline $\begin{array}{l}\text { Vera smarter home } \\
\text { control }\end{array}$ & $\begin{array}{l}\text { It offers smart home controllers with } \\
\text { good device and software compatibility }\end{array}$ & $\begin{array}{l}\text { (1) The best feature is its support of remote access: } \\
\text { the MiOS software. It allows connecting the } \\
\text { system with any devices, which have a friendly } \\
\text { GUI helping the users to achieve maximum } \\
\text { control and energy efficiency; } \\
\text { (2) The support service works by email, telephone } \\
\text { and live chat }\end{array}$ & $\begin{array}{l}\text { (1) It is not compatible with home } \\
\text { theater systems; } \\
\text { (2) It also does not support voice } \\
\text { control technology }\end{array}$ & [107] \\
\hline WeBee & $\begin{array}{l}\text { It is an app that allows to be connected to } \\
\text { all the appliances in the smart home }\end{array}$ & $\begin{array}{l}\text { (1) It provides personal suggestions customized to } \\
\text { the users habits, lifestyle and schedule in order to } \\
\text { save energy and improve efficiency; } \\
\text { (2) Compatible with any other smart technology }\end{array}$ & - & [108] \\
\hline $\begin{array}{l}\text { Whirlpool Smart } \\
\text { appliances }\end{array}$ & $\begin{array}{l}\text { It is a HA system constituted by all the } \\
\text { home appliances that can communicate } \\
\text { each other }\end{array}$ & $\begin{array}{l}\text { It enables the user of having full control over the } \\
\text { smart appliances and can be set on pause when } \\
\text { the energy costs are high }\end{array}$ & $\begin{array}{l}\text { (1) It only works with Whirlpool appliances; } \\
\text { (2) It is closed sourced }\end{array}$ & [109] \\
\hline Wink & $\begin{array}{l}\text { (1) The system works with the most } \\
\text { common home control technologies; } \\
\text { (2) It has to be coupled with a } \\
\text { Hub system }\end{array}$ & $\begin{array}{l}\text { (1) The system is compatible with many devices of } \\
\text { different brands; } \\
\text { (2) It is easy to use for connecting different devices }\end{array}$ & $\begin{array}{l}\text { The Hub Wi-Fi sometimes does not } \\
\text { work properly }\end{array}$ & [110] \\
\hline
\end{tabular}




\section{Discussion}

In this section, the actual and future benefits and challenges related to the presented technologies will be discussed from different perspectives.

\subsection{Challenges Related to Smart Home Technologies}

The need for energy management systems is thus motivated by (i) the possibility of efficiently managing energy flows by using intelligent commands and a supervision system that is capable of interacting with both loads and generations to balance demand and supply, and (ii) the possibility of interacting with the external network to plan the production levels that are necessary to benefit economically from exchanging energy with the grid [111].

Integration of the forecasting models, which are able to predict hourly power generation according to the weather forecasting inputs could make an optimal operation schedule in such a way that economically optimized power dispatch can be maintained to fulfill certain load demand. Some studies show that this would reduce daily costs by $28 \%$. Further research could be performed to improve this method by including more relevant factors, such as the industrial and commercial profiles of a city or region [112].

Peak demand charge is one of the major components of a customer's power bill and is the calculation of the amount of energy required during the peak demand periods. To cover the peak demand, utility companies are compelled to purchase reserves that remain untapped most of the time and are, only to be used for short periods of high demand or during failure of other reserves.

Furthermore, smart homes are basically equipped with renewable energy generation technologies. Unfortunately, local energy generation from renewable energy sources (RES) and energy requirements are misaligned. Therefore, a smart technology might be able to modify indoor environmental conditions to time shift energy requirements from peak to off-peak hours. Moreover, if the building is equipped with an electric storage, energy from RES can be used to charge the storage when the electricity cost is low, and discharge the storage during high-cost periods. Thus, the use of storage in conjunction with RES might help optimize the cost effectiveness of a smart home. A renewable energy time shift is particularly valuable for intermittent sources [113].

\subsection{Challenges, Benefits, and Motivations Related to the Users}

Due to the direct involvement of end-users in the energy management of the power grid, the issue of load level has gained increasing interest in the last few years also considering that the unpredictable human factors can have significant influences on DR system's performance and the energy management of homes. A study conducted in Denmark investigated the heat usage in 290 identical homes. It was found that the highest heat consumption was up to twenty times higher than the lowest due to the occupant's behavior [114]. Users' habits play a key role related to energy use $[115,116]$. Other studies $[34,111,117]$ pointed out that users can efficiently operate in a real-time frame to optimally control all major residential energy loads, storage and production components while properly considering the customers' preferences and comfort level. The main objective functions for the operation of each household appliance are electricity payment minimization [22]. Therefore, users are becoming aware that they can manage energy resources and have an active role in the operation of the energy system by using the following strategies related to smart grids via their smart home technologies:

(i) Rationalizing the amount of energy required from controllable loads: smart grids enable providers to better control and plan production and to adjust the price levels of electricity. Previous studies have systematized approaches to home energy management, which may belong to one or any mix of the following three categories: (i) a technology-oriented approach; (ii) an economically-oriented approach or (iii) an environmentally-oriented approach. 
(ii) Wisely scheduling running times for smart appliances that are likely to be shifted in time. Households' involvement in cutting their overall energy demand and the evening peaks in energy usage is still being explored. Currently, a lot of interest is being directed to making homes more flexible energy users. This flexibility aims to modify households' load shape thanks to feedback on real-time energy usage and an indication from them of which tariff information they found useful in relation to optimizing their energy costs.

(iii) Turning themselves into potential carbon-free generators of energy, through the use of renewable resources: so far, the focus of smart grid technologies has been on integrating RES into the grid to reduce the cost of power generation. Integrating these resources requires storage systems. Load/generation shifting can be used by customers, utility providers, or renewable power producers to take advantage of the different electricity rates available at various times of the day [113].

Although the potential benefits of an active management of homes' energy use are significant, households as energy users are still subject to several concerns that could inhibit a rapid adoption of smart home technologies. The most significant concern is that, in order to maximize the benefits of smart grids, utility providers' and suppliers' of energy management solutions must adapt existing technological infrastructures to new bidirectional and dynamic loads. Therefore, the capabilities and the advantages of these systems are currently not fully deployed. This is one reason why widespread adoption of smart technologies in homes has been hindered [118]. Several experiments conducted on users' behavior have demonstrated that energy management systems for residential applications allow energy costs to be reduced by about $18 \%$, while preserving the user comfort [22].

\subsection{Barriers and Futures Trends}

Future research should be continued to develop algorithms and to study human habits to improve the efficiency and flexibility of the energy management strategy [119]. The potential benefit of communicating households energy usage in a systemic context, i.e., considering the dwelling as a part of a smart grid, has also been explored and has been recognized as a significant potential driver for the deployment of energy management solutions in households [45].

The effect of feedback on end-users has been proven to be more effective the more direct it is. Furthermore, the representation of data should ideally be personalized to fit end-users' needs, habits, and education. Supplying users with the possibility of comparing their home energy usage with benchmarks as well as with their own historical data has also been shown to be an advantage. However, what is a relevant comparison will also vary among the users. For instance, a few user may be interested in comparing their own usage with that of others, hence adding a reference element, while others may not be interested at all in competing in this context. Moreover, users may by grouped according to different rules, e.g., per homes of comparable size, buildings with analogous occupation time, or buildings with similar average energy usages [45]. The most challenging aspect of users' motivation is that whichever type of feedback is used, the technology needs to be continually developed to meet the challenge of domestication. The process implies that end-users adapt the technology according to their own needs and expectations. However, this process has, from a visualization point of view, an adverse side effect [120]: any positive effect of any visualization methods used for end-users' benefit eventually stop as part of the domestication process. Consequently, any management system, independent of how effective it might prove to be, will only remain effective if the presentation of data is flexible and can be adjusted to vary over time [118]. The challenge lies in offering the end-users not only relevant data but also continual involvement in this adaptation and customization process.

Recently, the potential of offering gamification, i.e., the use of videogame elements and concepts from non-gaming contexts to improve user experience and engagement with an interface has started to be explored [121]. Having the option to compare own energy usage with that of others may include a potential gamification element. 
Finally, another significant barrier, represented by users' knowledge about smart technologies has to be taken into consideration to realize a proper home automation system able to interact with users. Not only do smart appliances have to be correctly installed and properly configured, but the users' knowledge of smart devices needs to be consistently increased as well as their awareness of energy management.

\section{Conclusions}

In this article, the concept of the smart home and the advent of the smart grid have been presented. Smart technologies and products available on the market that allow an intelligent energy management of homes have been reviewed. The technologies summarized in Table 1, which include both optimization-based and communication-based ones, have been evaluated. It was also discussed a general system's architecture and the barriers, challenges, benefits and future trends that future smart homes and grids will face. Efficient usage of electricity results in lowering peak load, reducing energy bills, and minimizing greenhouse gas emissions. In order to realize an effective integration of smart homes into a smart grid, the migration towards bi-directional communication networks has to be fostered, and well-tuned home automation system has to be designed.

It is expected that the work described in this article might channel efforts towards the choice of a more efficient, user-friendly system for smart home [21].

The current trend indicates that in the near future, more and more smart homes will be built and the technology inside them will grow very fast in order to create a more responsive and active environment able to respond to the users' needs. In this regard, companies that produce software and home appliances are creating new applications and technologies specifically targeted at smart homes. The effect will be threefold: (i) in the future, homes will not be the same as today; (ii) existing infrastructures, such as smart grids, will be continually improved, and (iii) people's everyday lives will inevitably be affected by changes in available technologies and systems.

Concerning the role and motivation of the potential users of the energy management technologies that are being developed, much still remains to be explored before these systems will satisfy users' needs and help them fulfill their full potential as active and aware users. However, providing end-users with systems that are tailored to fit end-user profiles is a good start for providing real-time feedback. The option to measure performance against relevant benchmarks and make comparisons with other households' performances should preferably be included in such systems. The challenge to build in a well-functioning flexibility into the systems' presentation of data is likely to remain a continuous challenge for these systems as the users will gradually get used to any means of visualization of data and want it to be changed regularly. The need to provide homes with a systemic context calls for more cooperation with the smart grid' managers at a systemic level and more end-user studies. Finally, the potential use of gamification elements should be further explored to keep up with the latest computer game industry into smart technologies.

Acknowledgments: This work was partially funded by the European Union's Seventh Framework Programme under grant agreement 608806, acronym CoSSMic, and by the European Union's Horizon 2020 Research and Innovation Programme under grant agreement 680529, acronym QUANTUM. The sole responsibility for the content of this article lies with the authors. It does not necessarily reflect the opinion of the European Commission (EC). The EC is not responsible for any use that may be made of the information this article contains. Finally, the authors would like to thank Michele Liziero, Antonio Fallacara and Claas Pinkernell for their support during the collection of data.

Author Contributions: The work presented in this article is the result of a collaboration of all authors. Gabriele Lobaccaro and Erica Löfström analyzed the literature on the subject. Gabriele Lobaccaro, Erica Löfström and Salvatore Carlucci contributed in writing the manuscript and editing the document. Salvatore Carlucci critically reviewed the article. Gabriele Lobaccaro and Salvatore Carlucci actively contributed to finalize the manuscript. All authors contributed to the discussion and conclusion of this research.

Conflicts of Interest: The authors declare no conflict of interest. 


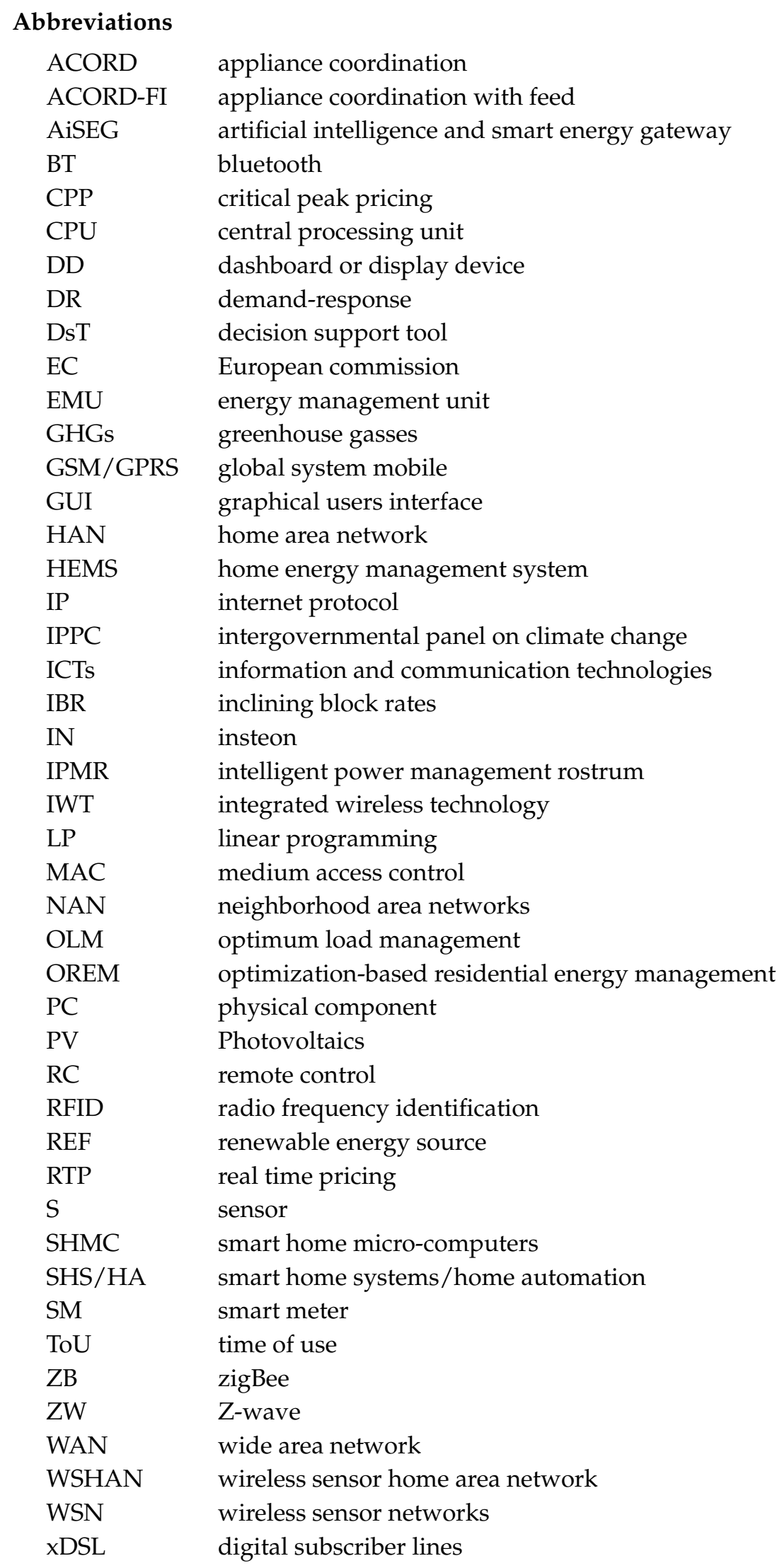




\section{References}

1. Comité Européen de Normalisation. Energy Performance of Buildings_Impact of Building Automation, Control, and Building Management; European Technical Standard EN 15232; CEN: Brussels, Belgium, 2012.

2. European Parliament. Directive 2010/31/EU of the European Parliament and of the Council of 19 May 2010 on the Energy Performance of Buildings; Directive 2010/31/EU; The European Parliament and the Council of the European Uninion: Brussels, Belgium, 2010.

3. European Climate Foundation. Roadmap 2050 Project. Available online: http:/ /www.roadmap2050.eu/ (accessed on 16 November 2015).

4. Graditi, G.; Ippolito, M.G.; Lamedica, R.; Piccolo, A.; Ruvio, A.; Santini, E.; Siano, P.; Izzo, G. Innovative control logics for a rational utilization of electric loads and air-conditioning systems in a residential building. Energy Build. 2015, 102, 1-17. [CrossRef]

5. Alam, M.R.; Alauddin, M.A. A review of smart homes-past, present, and future. IEEE Trans. Syst. Man Cybern. C Appl. Rev. 2012, 42, 1190-1203. [CrossRef]

6. Chan, M.; Estève, D.; Escriba, C.; Campo, E. A review of smart homes-present state and future challenges. Comput. Methods Progr. Biomed. 2008, 91, 55-81. [CrossRef] [PubMed]

7. Liyanage, C.D.S.; Chamin, M.; Iskandar, M.P. State of the art of smart homes. Eng. Appl. Artifi. Intell. 2012, $25,1313-1321$.

8. Satpathy, L. Smart Housing: Technology to Aid Aging in Place. New Opportunities and Challenges. Master's Thesis, Mississippi State University, Starkville, MS, USA, 2006.

9. Cook, D.J.; Das, S.K. How smart are our environments? An updated look at the state of the art. Pervasive Mob. Comput. 2007, 3, 53-73. [CrossRef]

10. Al-sumaiti, A.S.; Ahmed, M.H.; Salama, M.M. Smart home activities: A literature review. Electr. Power Compon. Syst. 2014, 42, 294-305. [CrossRef]

11. Ding, D.; Cooper, R.A.; Pasquina, P.F.; Fici-Pasquina, L. Sensor technology for smart homes. Maturitas 2011, 69, 131-136. [CrossRef] [PubMed]

12. Somayya, R.; Ramaswamy, R. Smart homes. In Proceedings of the 2nd International Symposium on Computational and Business Intelligence, New Delhi, India, 7-8 December 2014.

13. Le, Q.; Nguyen, H.; Barnett, T. Smart homes for older people: Positive aging in a digital world. Future Internet 2012, 4, 607-617. [CrossRef]

14. Kok, K.; Karnouskos, S.; Dimeas, N.D.A.; Weidlich, A.; Warmer, C.; Strauss, P.; Buchholz, B.; Drenkard, S.; Hatziargyriou, N.; Lioliou, V. Smart houses for a smart grid. In Proceedings of the 20th International Conference and Exhibition on Electricity Distribution (CIRED 2009), Prague, Czech Republic, 8-11 June 2009.

15. Roncero, J.R. Integration is key to smart grid management. In Proceedings of the IET-CIRED Seminar on SmartGrids for Distribution, Frankfurt, Germany, 23 June 2008.

16. Erol-Kantarci, M.; Mouftah, H.T. Wireless sensor networks for domestic energy management in smart grids. In Proceedings of the 25th Biennial Symposium on Communications, Kingston, ON, Canada, 12-14 May 2010.

17. Costanzo, G.T.; Zhu, G.; Anjos, M.F.; Savard, G. A system architecture for autonomous demand side load management in smart buildings. IEEE Trans. Smart Grid 2012, 3, 2157-2165. [CrossRef]

18. World Business Council for Sustainable Development. Transforming the Market: Energy Efficiency in the Buildings; World Business Council for Sustainable Development: Brussels, Belgium, 2009.

19. Kailas, A.; Cecchi, V.; Mukherjee, A. A survey of communications and networking technologies for energy management in buildings and home automation. J. Comput. Netw. Commun. 2012, 1-12. [CrossRef]

20. Darby, S. The Effectiveness of Feedback on a Review for Defra of the Literature on Metering, Billing and Direct Displays. Environmental Change Institute-University of Oxford: Oxford, UK, 2006.

21. Javaid, N.; Khan, I.; Ullah, M.N.; Mahmood, A.; Farooq, M.U. A survey of home energy management systems in future smart grid communications. In Proceedings of the IEEE 8th International Conference on Broadband, Wireless Computing, Communication and Applications, Compiegne, France, 28-30 October 2013.

22. Siano, P.; Graditi, G.; Atrigna, M.; Piccolo, A. Designing and testing decision support and energy management systems for smart homes. J. Ambient Intell. Hum. Comput. 2013, 4, 651-661. [CrossRef] 
23. Han, J.; Choi, C.; Park, W.; Lee, I. Green home energy management system through comparison of energy usage between the same kinds of home appliances. In Proceedings of the 15th IEEE International Symposium on Consumer Electronics, Singapore, 14-17 June 2011.

24. Lien, C.; Bai, Y.; Lin, M. Remote-controllable power outlet system for home power management. IEEE Trans. Consum. Electron. 2007, 53, 1634-1641. [CrossRef]

25. Mohsenian-Rad, A.-H.; Leon-Garcia, A. Optimal residential load control with price prediction in real-time electricity pricing environments. IEEE Trans. Smart Grid 2010, 1, 120-133. [CrossRef]

26. Erol-Kantarci, M.; Mouftah, H. Wireless sensor networks for cost-efficient residential energy management in the smart grid. IEEE Trans. Smart Grid 2011, 2, 314-325. [CrossRef]

27. Khan, I.; Mahmood, A.; Javaid, N.; Razzaq, S.; Khan, R.D.; Ilahi, M. Home energy management systems in future smart grids. Available online: http:/ /arxiv.org/abs/1306.1137 (accessed on 10 November 2015).

28. Graditi, G.; Ippolito, M.G.; Telaretti, E.; Zizzo, G. An innovative conversion device to the grid interface of combined RES-based generators and electric storage systems. IEEE Trans. Ind. Electron. 2015, 62, 2540-2550. [CrossRef]

29. Berardi, U. A cross-country comparison of the building energy consumptions and their trends. Resour. Conserv. Recycl. 2016. in press. [CrossRef]

30. Murata, A.; Kondou, Y.; Hailin, M.; Weisheng, Z. Electricity demand in the Chinese urban household-sector. Appl. Energy 2008, 85, 1113-1125. [CrossRef]

31. Boegle, A.; Singh, D.; Sant, G. Estimating technical energy saving potential from improved appliance efficiency in indian households in American council for an energy-efficient economy. In Proceedings of the 16th Biennal ACEEE Summer Study Energy Efficiency in Buildings, Pacific Grove, CA, USA, 15-20 August 2010.

32. Morishita, C.; Ghisi, E. Assessment of the Impact of energy-efficient household appliances on the electricity consumption in the residential sector of Brazil. In Proceedings of World Energy Council Conference, Montreal, Quebec, QC, Canada, 12-16 September 2010.

33. Di Silvestre, M.L.; Graditi, G.; Sanseverino, E.R. A generalized framework for optimal sizing of distributed energy resources in micro-grids using an indicator-based swarm approach. IEEE Trans. Ind. Inform. 2014, 10, 152-162. [CrossRef]

34. Jiang, B.; Fei, Y. Smart home in smart microgrid: A cost-effective energy ecosystem with intelligent hierarchical agents. IEEE Trans. Smart Grid 2014, 6, 3-13. [CrossRef]

35. IPCC. Intergovernmental Panel on Climate Change. In Climate Change 2014: Mitigation of Climate Change; Cambridge University Press: New York, NY, USA, 2014.

36. Fitzgerald, M. Finding and Fixing a Homes Power Hogs. 2008. Available online: http://www.nytimes.com/ 2008/07/27/technology/27proto.html (accessed on 16 November 2015).

37. Gellings, C.W. The Smart Grid: Enabling Energy Efficiency and Demand Response. CRC Press: Boca Raton, FL, USA, 2009.

38. Ahmad, A.; Latif, K.; Javaid, N.; Khan, A.; Qasim, U. Density controlled divide-and-rule scheme for energy efficient ruoting in wireless sensor networks. In Proceedings of the 26th IEEE Canadian Conference on Electrical and Computer Engineering (CCECE2013), Regina, SK, Canada, 5-8 May 2013.

39. Khan, M.Y.; Javaid, N.; Khan, M.A.; Javaid, A.; Khan, Z.A.; Qasim, U. Hybrid DEEC: Towards efficient energy utilization in wireless sensor networks. World Appl. Sci. J. 2013, 22, 126-132.

40. Aslam, M.; Shah, T.; Javaid, N.; Rahim, A.; Rahman, Z.; Khan, Z.A. CEEC: Centralized energy efficient clustering a new routing protocol for WSNs. In Proceedings of the 9th IEEE Communications Society Conference on Sensor, Mesh and Ad Hoc Communications and Networks (SECON), Seoul, Korea, 18-21 June 2012.

41. Aman, S.; Simmhan, Y.; Prasanna, V.K. Energy management systems: State of the art and emerging trends. IEEE Commun. Mag. 2013, 51, 114-119. [CrossRef]

42. Ehrhardt-Martinez, K.; Donnelly, K.A.; Laitne, J. Advanced Metering Initiatives and Residential Feedback Programs: A Meta-Review for Household Electricity-Saving Opportunities; American Council for an Energy-Efficient Economy: Washington, DC, USA, 2010.

43. The BEHAVE Energy Conference. The BEHAVE Energy Conference. 29 October 2014. Available online: http://behaveconference.com/programme/ (accessed on 8 January 2016). 
44. Löfström, E. Visualisera Energi i Hushåll Avdomesticeringen av Sociotekniska System och Individ Respektive Artefaktbunden Energianvändning. Linköping University, Department of Technology and Social Change: Linköping, Sweden, 2008.

45. Löfström, E. Smart meters and people using the grid: Exploring the potential benefits of AMR-technology. Energy Procedia 2014, 58, 65-72. [CrossRef]

46. Güngör, V.C.; Sahin, D.; Kocak, T.; Ergüt, S.; Buccella, C.; Cecati, C. Smart grid technologies: Communication technologies and standards. IEEE Trans. Ind. Inform. 2011, 7, 529-539. [CrossRef]

47. Parikh, P.P.; Kanabar, M.G.; Sidhu, T.S. Opportunities and challenges of wireless communication technologies for smart grid applications. In Proceedings of the IEEE Proceedings on Power and Energy Society General Meeting, Minneapolis, MN, USA, 25-29 July 2010.

48. Lee, J.; Su, Y.; Shen, C. A comparative study of wireless protocols: Bluetooth, UWB, ZigBee, and Wi-Fi. In Proceedings of the 33rd Annual Conference of the IEEE Industrial Electronics Society (IECON), Taipei, Taiwan, 5-8 November 2007.

49. Rafiei, M.; Elmi, S.M.; Zare, A. Wireless communication protocols for smart metering applications in power distribution networks. In Proceedings of the 17th Conference on Electrical Power Distribution Networks (EPDC), Tehran, Iran, 2-3 May 2012.

50. Al-Qutayri, M.; Jeedella, S. Integrated Wireless Technologies for Smart Homes Applications. In Smart Home Systems; INTECH Open Access Publisher: Rijeka, Croatia, 2010; pp. 17-42.

51. Gonnot, T.; Saniie, J. User defined interactions between devices on a 6LoWPAN network for home automation. In Proceedings of the IEEE International Technology Management Conference (ITMC), Chicago, IL, USA, 12-15 June 2014.

52. Ma, X.; Luo, W. The Analysis of 6LowPAN Technology. In PACIIA '08. Pacific-Asia Workshop on Computational Intelligence and Industrial Application; IEEE: Piscataway, NJ, USA, 2008; Volume 1, pp. 963-966.

53. Davies, A.C. An overview of Bluetooth wireless technology TM and some competing LAN standards. In Proceedings of the 1st IEEE International Conference on Circuits and Systems for Communications, St. Petersburg, Russia, 26-28 June 2002.

54. Bisdikian, C. An overview of the Bluetooth wireless technology. IEEE Commun. Mag. 2002, 39, 86-94. [CrossRef]

55. Dash7-Alliance. DASH7 Technology. Available online: http://www.dash7-alliance.org/ (accessed on 15 February 2016).

56. Anders. EnOcean Technology-Energy Harvesting Wireless. EnOcean. Available online: http:/ / www.enocean.com/en/home/ (accessed on 14 September 2014).

57. Learn GSM. Available online: http://www.tutorialspoint.com/gsm/gsm_specification.htm (accessed on 15 February 2016).

58. DevLab—Development Laboratories, MyriaNed Wireless Sensor Network, DevLab. Available online: http:/ / www.devlab.nl/projects/myrianed/ (accessed on 20 February 2016).

59. Hester, L.; Huang, Y.; Andric, O.; Allen, A.; Chen, P. NeuRon ${ }^{\mathrm{TM}}$ netform: A self-organizing wireless sensor network. In Proceedings of the Eleventh International Conference on Computer Communications and Networks, Miami, FL, USA, 14-16 October 2002.

60. Xiaolin, J.; Quanyuan, F.; Taihua, F.; Quanshui, L. RFID technology and its applications in Internet of Things (IoT). In Proceedings of the 2nd International Conference on Consumer Electronics, Communications and Networks (CECNet), Yichang, China, 21-23 April 2012.

61. Porcino, D.; Hirt, W. Ultra-wideband radio technology: Potential and challenges ahead. IEEE Commun. Mag. 2003, 41, 66-74. [CrossRef]

62. Lee, J.S.; Chuang, C.C.; Shen, C.C. Applications of short-range wireless technologies to industrial automation: A ZigBee approach. In Proceedings of the Fifth Advanced International Conference on Telecommunications, Venice, Italy, 24-28 May 2009.

63. Wang, W.; Xu, Y.; Khanna, M. A survey on the communication architectures in smart grid. Comput. Netw. 2011, 55, 3604-3629. [CrossRef]

64. Knite, M. How Safe is Z-Wave? IEEE J. IET Comput. Control Eng. 2006, 19, 18-23.

65. Tsang, K.F.; Lee, W.C.; Lam, K.L.; Tung, H.Y.; Xuan, K. An integrated ZigBee automation system: An energy saving solution. In Proceedings of the 14th International Conference on Mechatronics and Machine Visionin Practice, Xiamen, China, 4-6 December 2007. 
66. ZigBee Alliance. 2014. Available online: http://www.zigbee.org/About/AboutTechnology/ZigBee Technology.aspx (accessed on 1 September 2014).

67. Berlad, A.L.; Salzano, F.J.; Batey, J. On enthalpy management in small buildings. Energy 1976, 1, 429-443. [CrossRef]

68. Beaudin, M.; Zareipour, H. Home energy management systems: A review of modelling and complexity. Renew. Sustain. Energy Rev. 2015, 45, 318-335. [CrossRef]

69. LaMarche, J.; Cheney, K.; Roth, K.; Sachs, O.; Pritoni, M. Home Energy Management: Products \& Trends. In Proceedings of 17th Biennial ACEEE Summer Study on Energy Efficiency in Buildings, Pacific Grove, CA, USA, 12-17 August 2012.

70. GreenTech Media. Smart Grid HAN Strategy Report 2011: Technologies, Market Forecast, and Leading Players. GreenTech Media, 2011. Available online: http://www.greentechmedia.com/research/report/ smart-grid-han-strategy-2011. (accessed on 7 October 2014).

71. Cisco. Bringing the Smart Grid into the Home: The Value of Home Energy Management for Utilities. Available online: http:/ / poweronltd.ca/wp-content/uploads/2011/03/Bringing-the-Smart-Grid-into-theHome.pdf (accessed on 15 September 2014).

72. DigitalSTROM. DigitalSTROM System. Available online: http://www.digitalstrom.com/en/ (accessed on 18 September 2014).

73. Makad Energy. Consumer Managed Energy at Your Fingertips. Available online: http://www.makadenergy. com/ (accessed on 18 September 2014).

74. Gobierno de Espana-Ministero de Industria, Energia y Turismo. e-GOTHAM Sustainable Smart Grid Open System. Available online: http:/ / www.e-gotham.eu/ (accessed on 15 August 2014).

75. EmonCMS. Emoncms Open-Source Energy Visualisation. OpenEnergyMonitor. Available online: http:/ /emoncms.org/ (accessed on 18 September 2014).

76. Energy Team. Available online: http://www.energyteam.it/en/ (accessed on 20 February 2016).

77. Google. Google PowerMeter: A Google.org Project. Available online: http://www.google.com/ powermeter/about/ (accessed on 18 September 2014).

78. Savant. Energy Management Systems. Available online: http://www.savantsystems.com/energy_ management.aspx (accessed on 15 August 2014).

79. Panasonic. Energy Solutions for Homes. 2014. Available online: http://panasonic.net/es/solution-works / HouseEnergy/ (accessed on 15 August 2014).

80. Fisch, M.N.; Pinkernell, C.; Plesser, S.; Rumpe, B. The energy navigator-A web-platform for performance design and management. In Proceedings of the 7th International Conference on Energy Efficiency in Commercial Buildings (IEECB), Frankfurt, Germany, 18-19 April 2012.

81. Rao, P.B.; Uma, S.K. Raspberry Pi home automation with wireless sensors using smart phone. Int. J. Comput. Sci. Mob. Comput. 2015, 4, 797-803.

82. Robles, J.; Kim, T. Application, systems and methods in smart home technolog: A review. Int. J. Adv. Sci. Technol. 2010, 15, 37-48.

83. Carlucci, S.; Causone, F.; De Rosa, F.; Pagliano, L. A review of indices for assessing visual comfort with a view to their use in optimization processes to support building integrated design. Renew. Sustain. Energy Rev. 2015, 47, 1016-1033. [CrossRef]

84. Carlucci, S.; Pagliano, L. A review of indices for the long-term evaluation of the general thermal comfort conditions in buildings. Energy Build. 2012, 53, 194-205. [CrossRef]

85. Arduino. Available online: http://arduino.cc/ (accessed on 18 September 2014).

86. Banana Pi. Banana Pi-A Highend Single-Board Computer. Available online: http://www.bananapi.org/ (accessed on 18 September 2014).

87. BeagleBone Black. Available online: http://beagleboard.org/black (accessed on 18 September 2014).

88. RaspberryPi. Available online: http://www.raspberrypi.org/ (accessed on 18 Septembe 2014).

89. Libelium. Libelium-Waspmote. Available online: http://www.libelium.com/products/waspmote/ (accessed on 11 January 2016).

90. British Gas. Control Your Energy-Technologies to Control the Energy Use at Home. 2014. Available online: http:/ / www.britishgas.co.uk/smarter-living/control-energy.html (accessed on 15 September 2014).

91. Control4. Control4 Home Automation. Available online: http://www.control4.com/ (accessed on 19 September 2014). 
92. Creston. Creston Smart Home Technology, Home Automation and Lighting Control Systems. Available online: http:/ / www.crestron.eu/?q=en (accessed on 19 September 2014).

93. GE Appliances. GE Brillion ${ }^{\mathrm{TM}}$ Connected Appliances. General Electric. Available online: http:/ / www.geappliances.com/connected-home-smart-appliances/ (accessed on 7 October 2014).

94. HomeSeer. HomeSeer-Home Control System. Available online: http://www.homeseer.com/ (accessed on 20 January 2016).

95. Honda. Honda Smart Home US. Available online: http://www.hondasmarthome.com/ (accessed on 19 September 2014).

96. Apple. HomeKit. Available online: https://developer.apple.com/homekit/ (accessed on 15 September 2014).

97. Lowe's. Iris by Lowe's Smart Home. Available online: https://www.irisbylowes.com/ (accessed on 20 January 2016).

98. KNX. KNX Technology. 8 May 2013. Available online: http://www.knx.org/no/knx-standard/ introduksjon/ (accessed on 15 September 2014).

99. LG. LG Smart ThinQ. 1 February 2012. Available online: http://www.lg.com/us/discover/smartthinq/ thinq (accessed on 7 October 2014).

100. Echelon Corporation. LONWORKS. Available online: http://www.rtaautomation.com/technologies/ lonworks / (accessed on 10 April 2016).

101. Nexia. Nexia Home Intelligence. Available online: http://www.nexiahome.com/ (accessed on 20 January 2016).

102. OpenHAB. Available online: http://www.openhab.org/index.html (accessed on 19 September 2014).

103. Panasonic. Panasonic Smart Cloud Services. 21 August 2012. Available online: http://panasonic.co.jp/ corp/news/official.data/data.dir/2012/08/en120821-9/en120821-9.html (accessed on 7 October 2014).

104. Samsung. SmartThings-Smart Home Intelligent Living. Available online: https://www.smartthings.com/ (accessed on 20 January 2016).

105. Staples. Staples Connect. Available online: http://www.staples.com/sbd/cre/marketing/staples-connect/ staples-connect.html (accessed on 20 January 2016).

106. UPnP. UPnP Forum. Available online: http://upnp.org/ (accessed on 7 October 2014).

107. Vera Control, Ltd. Vera Smarter Home Control. Available online: http://getvera.com/ (accessed on 20 January 2016).

108. WeBee. Webee: The Real Smart Home. WeBee Universe. Available online: https://www.indiegogo.com/ projects / webee-the-real-smart-home (accessed on 19 September 2014).

109. Whirlpool. Whirlpool Smart Appliances with 6th Sense Live Technology. Available online: http:/ / www.whirlpool.com/smart-appliances/ (accessed on 7 October 2014).

110. Wink. Wink-A Simpler Way to a Smarter Home, Wink Inc. Available online: http://www.wink.com/ (accessed on 20 January 2016).

111. Graditi, G.; Di Silvestre, M.L.; Gallea, R.; Sanseverino, E.R. Heuristic-based shiftable loads optimal management in smart micro-grids. IEEE Trans. Ind. Inform. 2015, 11, 271-280. [CrossRef]

112. Chen, C.; Duan, S.; Cai, T.; Liu, B.; Hu, G. Smart energy management system for optimal microgrid economic operation. IET Renew. Power Gener. 2010, 5, 258-267. [CrossRef]

113. Graditi, G.; Ippolito, M.G.; Telaretti, E.; Zizzo, G. Technical and economical assessment of distributed electrochemical storages for load shifting applications: An Italian case study. Renew. Sustain. Energy Rev. 2016, 57, 515-523. [CrossRef]

114. Fabi, V.; Andersen, R.V.; Corgnati, S.P. Window opening behaviour: Simulations of occupant behaviour in residential buildings using models based on a field survey. In Proceedings of the 7th Windsor Conference: The Changing Context of Comfort in an Unpredictable World, London, UK, 12-15 April 2012.

115. Gauthier, S.; Shipworth, D. Review of methods to map people's daily activity-Application for smart homes. Smart Innov. Syst. Technol. 2013, 22, 401-411.

116. Carlucci, S.; Lobaccaro, G.; Li, Y.; Catto Lucchino, E.; Ramaci, R. The effect of the randomization of stochastically-generated occupancy schedules on the energy performance of a multi-residential building. Energy Build. 2016. under review.

117. Miller, M.; Griendling, K.; Mavris, D. Exploring human factors effects in the smart grid system of systems demand response. In Proceedings of the International Conference System of Systems Engineering (SoSE), Genova, Italy, 16-19 July 2012. 
118. Löfström, E. Visuaizing Energy in Households. Ph.D. Thesis, Linköping University, Linköping, Sweden, 2008.

119. Zhou, Y.; Chen, Y.; Xu, G. Distributed energy resources with home energy management in smartgrid. In Proceedings of the 23rd International Symposium on Industrial Electronics (ISIE), Istanbul, Turkey, 1-4 June 2014; pp. 2578-2583.

120. Hirsch, E.; Silverstone, R. Consuming Technologies: Media and Information in Domestic Spaces; Routledge: London, UK; New York, NY, USA, 1992.

121. Salen, K.; Zimmermann, E. Rules of Play: Game Design Fundamentals. MIT Press: Boston, MA, USA, 2004.

(C) 2016 by the authors; licensee MDPI, Basel, Switzerland. This article is an open access article distributed under the terms and conditions of the Creative Commons Attribution (CC-BY) license (http:/ / creativecommons.org/licenses/by/4.0/). 